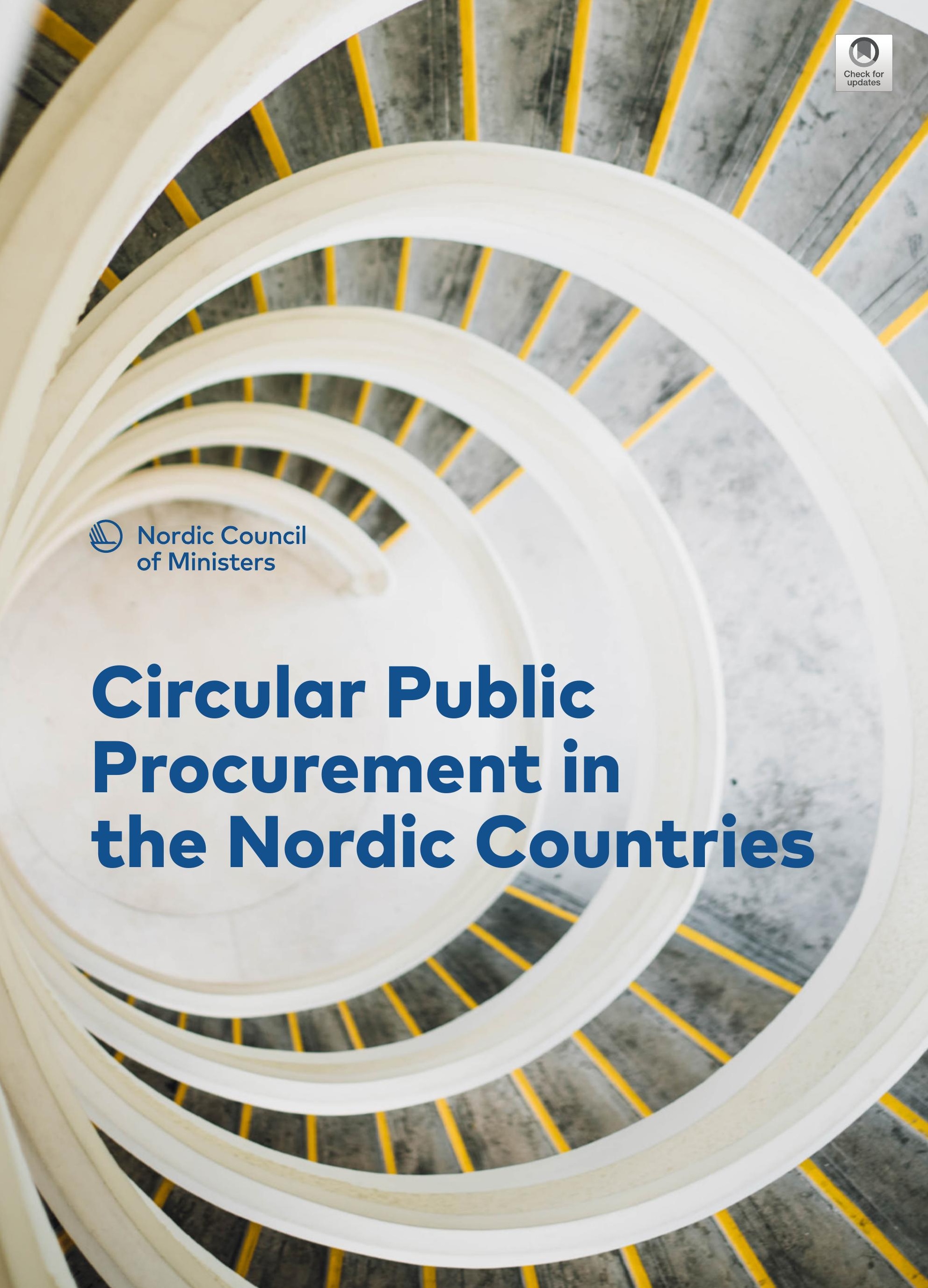





\section{Circular Public Procurement in the Nordic Countries}

Katriina Alhola, Hanna Salmenperä, Sven-Olof Ryding and Niels J. Busch

TemaNord 2017:512 


\section{Circular Public Procurement in the Nordic Countries}

Katriina Alhola, Hanna Salmenperä, Sven-Olof Ryding and Niels J. Busch

ISBN 978-92-893-4899-7 (PRINT)

ISBN 978-92-893-4900-0 (PDF)

ISBN 978-92-893-4901-7 (EPUB)

http://dx.doi.org/10.6027/TN2017-512

TemaNord 2017:512

ISSN 0908-6692

Standard: PDF/UA-1

ISO 14289-1

(c) Nordic Council of Ministers 2017

Cover photo: unsplash.com

Print: Rosendahls

Printed in Denmark

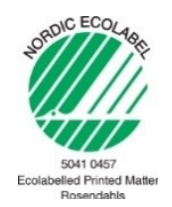

Although the Nordic Council of Ministers funded this publication, the contents do not necessarily reflect its views, policies or recommendations.

\section{Nordic co-operation}

Nordic co-operation is one of the world's most extensive forms of regional collaboration, involving Denmark, Finland, Iceland, Norway, Sweden, the Faroe Islands, Greenland, and Åland.

Nordic co-operation has firm traditions in politics, the economy, and culture. It plays an important role in European and international collaboration, and aims at creating a strong Nordic community in a strong Europe.

Nordic co-operation seeks to safeguard Nordic and regional interests and principles in the global community. Shared Nordic values help the region solidify its position as one of the world's most innovative and competitive. 


\section{Contents}

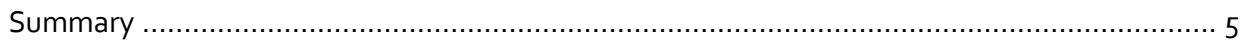

Preface

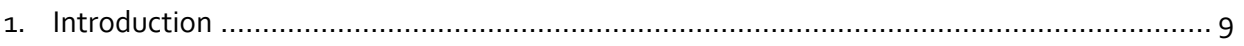

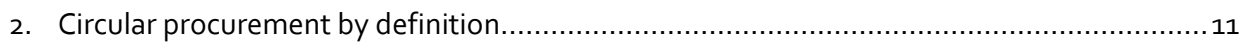

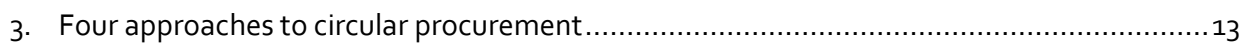

4. Current status of circular public procurement - a country review...................................15

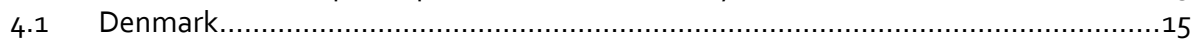

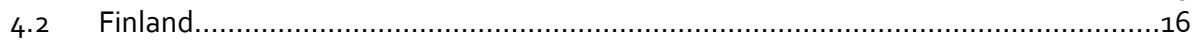

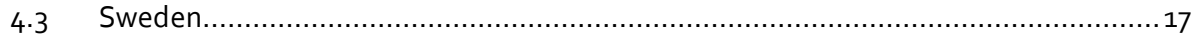

5. Aspects of circular procurement - a method for criteria analysis and case selection.............21

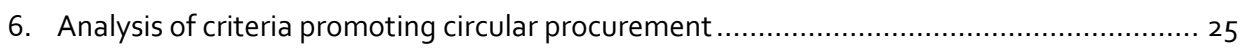

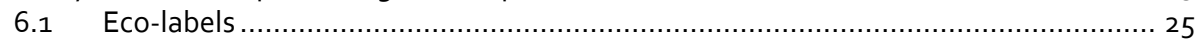

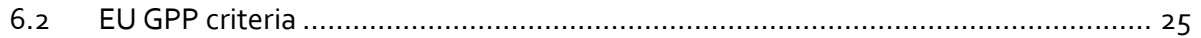

6.3 National procurement criteria supporting circular aspects .................................... 26

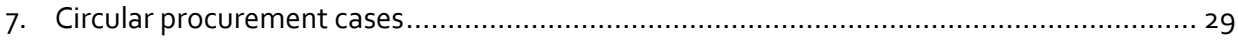

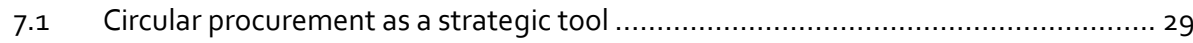

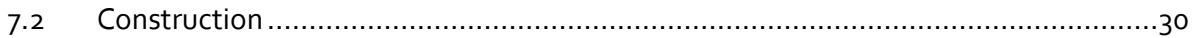

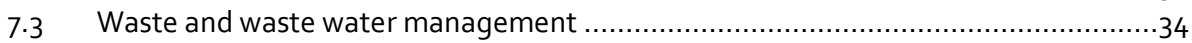

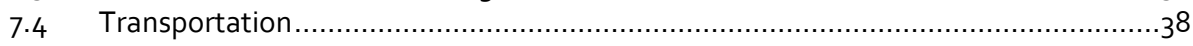

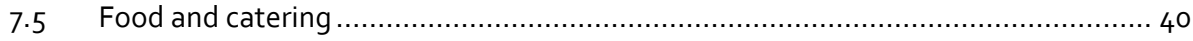

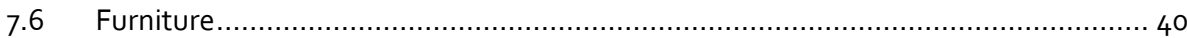

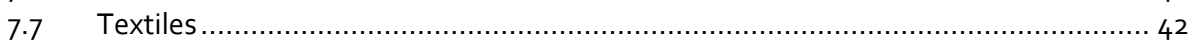

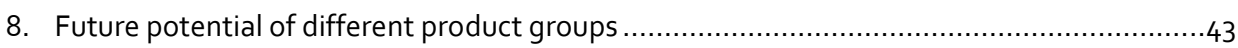

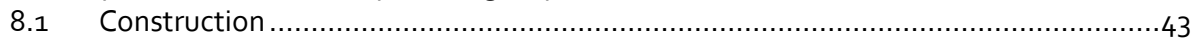

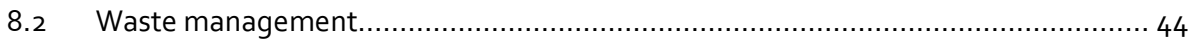

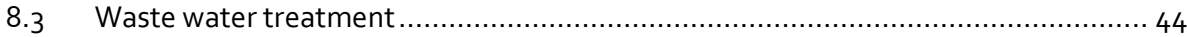

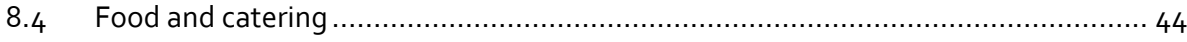

8.5 Public transportation and bio-based energy production .................................... 45

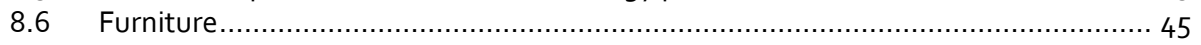

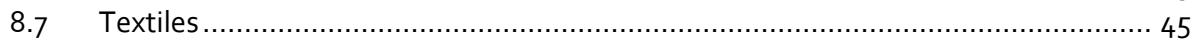

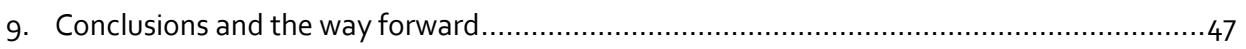

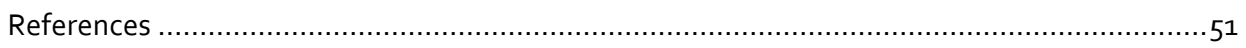

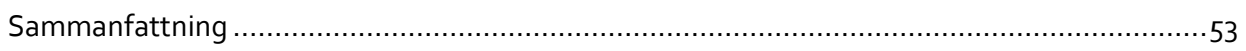

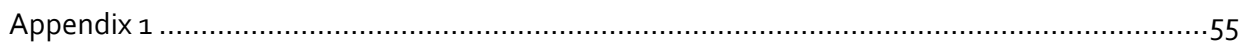





\section{Summary}

Circular procurement aims at promoting closed material loops and value retention, which can be achieved by favouring remanufacturing and reusing of products and materials several times in a circular manner without causing harmful environmental impacts, for example. Overall, circular procurement supports the goals of sustainable procurement aiming at value creation, social well-being and environmental improvements.

This study formulated four approaches to circular procurement, including the procurement of better quality products in circular terms, the procurement of new circular products, the use of business concepts that support the circular economy, and investments in circular ecosystems.

Good examples of circular procurement were identified in Denmark, Finland, Sweden and Norway. Potential sectors for circular procurement were identified, with relatively high purchasing volume and opportunities for creating a circular economybased business. In the construction and renovation of buildings, material and demolition waste could be recycled according to criteria and conditions stipulated in the contract. In the construction of road infrastructure, significant savings in material and money could be achieved by utilising secondary materials from the site or nearby. In the energy and transportation sectors, local circular systems could be created by developing bioenergy production. In waste water treatment, the circular economy could be promoted in terms of more efficient recycling of nutrients and the development of related technology and business concepts. Potential can also be found in product groups such as appliances, furniture and textiles.

The cases examined in this study imply that performance-based procurement, the use of life cycle costing and criteria concerning the reuse and recycling of materials have promoted circular procurement. In addition, procuring services instead of products could lead to environmental benefits.

Market dialogue and co-operation between different actors in supply chains is important for the future development of circular procurement. It is necessary to address the overall chain of manufacturers, suppliers, logistics, reprocessing and end markets as well as consumers. In addition, the education of procurers is essential for the adoption of new practices. 



\section{Preface}

Circular Economy (CE) is receiving increasing attention on the policy agendas as a means to overcome unsustainable production and consumption patterns, while allowing economic growth and efficient use of resources. The role of public procurement in promoting circular economy has been recognized important but yet not fully exploited opportunity by cities and municipalities in their transition towards circular societies. Resource efficiency and circular economy is one of the focus areas also in the current working program of the Nordic Council of Ministers Working Group for Sustainable Consumption and Production (HKP).

Today, many national action plans related to sustainable public procurement already set targets that stimulate circular economy, such as targets for waste reduction and recyclability. Also EU's green public procurement criteria and related national criteria exist for several product groups, which could help procuring units to buy products with higher recycled content and products and parts that could be better recycled. In addition, product-service systems, i.e. buying services instead of products could encourage "closed-loop" production and consumption cycles.

Albeit several initiatives and pilots in the area of circular public procurement exist, different approaches to circular procurement and the extent to which circular procurement is implemented, has remained unexplored. This study defines the framework and approaches to circular procurement and presents some best practices in the Nordic countries. In addition, the study identifies sectors and product groups that could be applicable to circular public procurement in the near future.

Sustainable public procurement could be one of the priority areas in future Nordic co-operation. The Nordic countries could also become frontrunners in circular public procurement and establish common guidelines, as numerous procurement cases promoting the circular economy and a shared interest in this matter already exist.

The study was carried out in Nordic co-operation by Finnish Environment Institute, IVL Swedish Environmental Research Institute and Copenhagen Resource Institute. The project was financed by the Nordic Council of Ministers, administrated by the Sustainable Consumption and Production Working Group and guided by a steering group consisting representatives from Denmark, Finland, Iceland, Norway and Sweden. 



\section{Introduction}

The circular economy (CE) is receiving increasing attention as a means to overcome unsustainable production and consumption patterns, while allowing for economic growth and the efficient use of resources. CE means that the value of products, materials and resources is maintained in the economy, in circulation, for as long as possible, and the generation of waste is minimised (European Commission, 2015). In recent years, interest towards circular procurement, i.e. promoting CE through procurement, has increased, and the possibilities public procurement has to promote the transition to a circular economy has been considered significant (Ellen MacArthur, 2015a).

Despite the lack of a standard definition, circular procurement refers to the procurement of products or services that follows the principles of CE. As a procurement process, it is expected to provide conditions and criteria that would stimulate energy and material savings and closed material loops, and spread innovative solutions and create markets for clean solutions, especially in waste prevention, material efficiency and recycling, such as smart waste management systems, the reuse of materials and products manufactured from secondary (recycled) raw materials (European Commission, 2014). This means that in the procurement and supply chain, waste would increasingly be regarded as a valuable raw material and thus the prevention and recovery of waste would provide competitive advantage to the bidder. Ideally, this could lead to the development of new products, technologies and business models.

Today, many national action plans related to Green Public Procurement (GPP) and sustainable procurement already set targets that stimulate circular procurement, e.g. targets for waste reduction and recyclability. For example, the EU Commission aims at emphasising aspects of the circular economy in procurement criteria, supporting increased uptake of GPP and leading by example in its own procurement and EU funding (European Commission, 2015). In addition, the EU's GPP criteria and national green procurement criteria already exist for several product groups, which could help procurement units to buy products with higher recycled content, and products and parts that could be better recycled. In addition, product-service systems, i.e. buying services instead of products, could encourage "closed-loop" production and consumption cycles (UNEP, 2015). Thus, one could assume that circular procurement is already being realised to some extent.

Public procurement in the Nordic countries is covered by common EU principles and the legal framework. The public procurement directive (2014/24/EU), renewed in 2014, allows procurement units to benefit from more opportunities to acquire innovative solutions, stimulates co-operation between different parties in the procurement process, and promotes the life cycle costing (LCC) method in decision making, which may help to incorporate the external costs of procurement and lead to the selection of sustainable and resource-efficient solutions. 
This study defines the framework and dimensions of circular procurement and presents some best practices of circular procurement in the Nordic countries. The study examines the extent to which circular public procurement is implemented in the Nordic countries by using case examples, interviews and discussions, as well as an analysis of procurement criteria that promote the circular economy. In addition, the study identifies sectors and product groups that could be applicable to circular public procurement in the near future and for which public demand could create markets. 


\section{Circular procurement by definition}

The common understanding and general descriptions of circular procurement relate to its role in promoting the circular economy. The circular economy, on the other hand, is defined as:

"A circular economy is one that is restorative and regenerative by design, and which aims to keep products, components and materials at their highest utility and value at all times, distinguishing between technical and biological cycles" (Ellen McArthur Foundation, 2015b). In a circular economy, "the value of products, materials and resources is maintained in the economy for as long as possible, and the generation of waste is minimised" (European Commission, 2015).

No standard description was found in the literature for circular procurement, but several definitions have been used (Table 1).

Table 1: Definitions for circular procurement

\begin{tabular}{|c|c|c|}
\hline Reference & Description & Focus \\
\hline Van Geet, 2014 . & $\begin{array}{l}\text { Circular Procurement = Circular Economy + Public } \\
\text { Procurement. }\end{array}$ & $\begin{array}{l}\text { Reuse. } \\
\text { Recycle. } \\
\text { Repair. } \\
\text { Refurbish. } \\
\text { Remanufacture. } \\
\text { Retrieve. }\end{array}$ \\
\hline $\begin{array}{l}\text { Green Deal, Circular } \\
\text { Procurement, } 2013 .\end{array}$ & $\begin{array}{l}\text { Circular procurement stimulates and creates demand } \\
\text { for goods that contribute to the circular economy. }\end{array}$ & Promoting a circular economy. \\
\hline MVO Nederland, 2015 & $\begin{array}{l}\text { The procurer ensures that the products are produced } \\
\text { in accordance with the principles of the circular econ- } \\
\text { omy and will be further processed after use, i.e. are } \\
\text { repairable and can be broken down into components } \\
\text { and/or materials at the end of their life cycle, which } \\
\text { can then be reused. }\end{array}$ & Recyclability and reuse of materials. \\
\hline NewForesight, 2014. & $\begin{array}{l}\text { The purchasing of products or services that follow the } \\
\text { principles of the circular economy: there are no nega- } \\
\text { tive side effects of production, waste does not exist, a } \\
\text { product or its elements are completely compostable } \\
\text { or reused, and toxic materials are eliminated. Energy } \\
\text { for production is from renewable sources. }\end{array}$ & Maximum closed loops. \\
\hline Philips, 2016. & $\begin{array}{l}\text { Circular procurement is about making choices early on } \\
\text { in the product creation process, so that materials and } \\
\text { components are suitable, at end-of-life, for repair, refur- } \\
\text { bishment or reuse. }\end{array}$ & $\begin{array}{l}\text { Selection of components and co- } \\
\text { operation in supply chain. }\end{array}$ \\
\hline
\end{tabular}


Definitions vary from general descriptions to a very strict demand of closed loops. Several focus areas can be found:

- Design of products that enable dismantling.

- Increase in cycling of products and raw materials.

- Minimisation of value destruction.

- Promotion of new business models.

- Elimination of hazardous chemicals and harmful substances.

Based on the above descriptions, this study proposes the following definition of circular procurement:

The procurement of competitively priced products, services or systems that lead to extended lifespan, value retention and/or remarkably improved and non-risky cycling of biological or technical materials, compared to other solutions for a similar purpose on the market.

Circular procurement is part of green and/or sustainable procurement aiming at value creation, social well-being and environmental improvements through closed and safe material loops. 


\section{Four approaches to circular procurement}

The principles of the circular economy can be promoted through public procurement in several ways. At least four different approaches were recognised that facilitate closed loops (Figure 1). This chapter will introduce these approaches, in which the focus will shift from better quality products to new and innovative products, new business concepts and finally to the creation of circular ecosystems.

1. Procurement of improved products and services by adding GPP-based "circular criteria"

Circular procurement can be promoted by adding "circular criteria", i.e. criteria for recyclability, reuse of materials, use of recycled materials, etc. This means buying improved products and services, such as paper made from $100 \%$ recycled material. Some of these criteria that support circular elements can be found in the GPP criteria palettes or eco-labels. This may be considered the simplest way or the first phase of buying in a circular manner.

2. Procurement of new and innovative products, services and materials promoting circular economy-based business

In accordance with the principles of the circular economy, public procurement could provide conditions that stimulate innovative solutions and create new business and markets for new products. This means products that are considerably better in terms of recyclability, recycled materials, disassembly, long lifespan, and so on. These are products that are commercialised but have not been on the market for a long time, or products that would be developed as a result of the procurement process. This approach highlights the procurer's ability to conduct an innovative procurement process. Examples of such products are textiles with $100 \%$ recycled content or building components made of recycled plastic.

3. Procurement of services and new business concepts

The focus of procurement could be on the process of procuring or on the business concept that responds the procurer's need, rather than on the product itself. These include product-service systems, leasing concept, shared use, buy-per-use and buying and selling back. More traditional examples include furniture leasing and car hiring. New thinking is needed for buying services instead of products, e.g. lighting for the next 30 years instead of lamps. 
4. Procurement promoting industrial symbiosis and circular ecosystems

This approach addresses large investments and the creation of ecosystems that call for commitment from different stakeholders. Circular ecosystems could be efficient platforms in supporting closed loops, and creating networks in which the waste from one actor would be used as a raw material for another. Examples include buses running by locally produced bioenergy, or construction sites that utilise materials effectively.

Figure 1: Four approaches to circular procurement

\begin{tabular}{|c|c|c|c|}
\hline $\begin{array}{c}\text { Procurement } \\
\text { including GPP } \\
\text { based "circular" } \\
\text { criteria }\end{array}$ & $\begin{array}{c}\text { Procurement } \\
\text { of new "circular" } \\
\text { products and } \\
\text { materials }\end{array}$ & $\begin{array}{l}\text { Procurement } \\
\text { of services and } \\
\text { new business } \\
\text { concepts }\end{array}$ & $\begin{array}{l}\text { Procurement } \\
\text { promoting } \\
\text { circular } \\
\text { ecosystems }\end{array}$ \\
\hline $\begin{array}{l}\text { Improved products } \\
\text { and services are } \\
\text { procured by adding } \\
\text { more GPP and circular } \\
\text { criteria to the tender } \\
\text { competition: } \\
\text { - Recyclability } \\
\text { - Share of recycled } \\
\text { materials } \\
\text { - Reuse } \\
\text { - Packaging material } \\
\text { - Etc. }\end{array}$ & $\begin{array}{l}\text { New products are } \\
\text { procured and/or } \\
\text { developed by } \\
\text { innovative public } \\
\text { procurement: } \\
\text { - Products that are } \\
\text { significantly better in } \\
\text { terms of recyclability, } \\
\text { share of recycled } \\
\text { materials, long } \\
\text { lifespan, } \\
\text { disassembly, etc. }\end{array}$ & $\begin{array}{l}\text { Product - service } \\
\text { systems are procured } \\
\text { and new approaches } \\
\text { are applied that } \\
\text { promote circular } \\
\text { aspects: } \\
\text { - Leasing concept } \\
\text { - Buy per use } \\
\text { - Shared use } \\
\text { - Buying and selling } \\
\text { back }\end{array}$ & $\begin{array}{l}\text { Investments are } \\
\text { made that stimulate } \\
\text { the development of } \\
\text { "circular } \\
\text { ecosystems" } \\
\text { - Develop or support } \\
\text { closed loops } \\
\text { - Create new } \\
\text { networks and } \\
\text { alliances } \\
\text { - "Waste as material" }\end{array}$ \\
\hline $\begin{array}{l}\text { Examples: } \\
\text { - Paper products } \\
\text { - ICT devices } \\
\text { - Packages } \\
\text { - Furniture }\end{array}$ & $\begin{array}{l}\text { Examples: } \\
\text { - Building components } \\
\text { of recycled material } \\
\text { - Textiles made of } \\
\text { recycled material }\end{array}$ & $\begin{array}{l}\text { Examples: } \\
\text { - Buying light instead } \\
\text { of lamps } \\
\text { - Leasing furniture } \\
\text { instead of buying it }\end{array}$ & $\begin{array}{l}\text { - Buses running by } \\
\text { locally produced } \\
\text { biogas } \\
\text { - Construction } \\
\text { projects with closed } \\
\text { material loops }\end{array}$ \\
\hline
\end{tabular}




\section{Current status of circular public procurement - a country review}

The Nordic countries share the EU-level objectives of stimulating the circular economy through public procurement. However, different means and channels may be used for implementation. This chapter reviews circular procurement initiatives at the governmental and municipal levels, and identifies the most important actors, organisations and networks that could promote the implementation of circular procurement, focusing on Denmark, Finland and Sweden.

\subsection{Denmark}

In Denmark, the main actors are the Ministry of Environment and Food (MEF) and the local municipalities. Some years ago MEF took the initiative to promote green procurement, and is now expanding the focus to circular procurement. The ministry has established a Partnership for Public Green Procurement, including twelve municipalities, two regions and a water supply company. They have established common goals for increasing green procurement, and several green procurement examples are available, some of which could also be called circular procurement. ${ }^{1}$ The partnership accounts for $17 \%$ of all public procurement in Denmark, or DKK 50 billion in total.

Besides this, circular procurement is a topic of the Forum on Sustainable Procurement - a national network established by MEF to share knowledge and keep procurers from public and private organisations updated on best practice, methods and tools for green procurement. Under the auspices of the forum there is work going on to develop examples of criteria for the procurement of circular solutions as well as advice on the procurement process. Best practice cases related to procurement to promote the circular economy are shared through a website, newsletters and events. ${ }^{2}$

Furthermore, MEF has developed guidelines and tools for Total Cost of Ownership (TCO) for selected product areas. The tools are available on a website where procurers can find green criteria ready to copy and paste into tender documents for a number of product areas. They do not all explicitly state circular procurement, but several of them include circular economy objectives. ${ }^{3}$

SKI, which is owned by the Danish state and by KL (the interest group and member authority for Danish municipalities) and which works to support the public sector

\footnotetext{
${ }^{1}$ http://www.gronneindkob.dk/

${ }^{2}$ http://ansvarligeindkob.dk/

3 http://csr-indkob.dk/compra/totalomkostninger/
} 
to submit attractive procurement agreements, has developed guidelines and tools for TCO calculations to inspire public procurers.

In addition, MEF has also launched a national task force on green public procurement that can help public and private procurers to learn about green procurement, including circular procurement. ${ }^{4}$

A number of municipalities have focused on the circular economy as part of the resource agenda, including a focus on how their purchasing function may contribute to better use of resources through more recycling and an extended lifespan of the products. The experiences are as far as possible shared via the forum mentioned above.

CradlePeople is an organisation for businesses, educational institutions, authorities and sustainability experts that brings procurers and suppliers together. CradlePeople is part of an international network that aims to be the platform for dialogue and networking, as intermediaries between producers, experts and the authorities. ${ }^{5}$

\subsection{Finland}

In Finland, there is a national focus on public procurement in the fields of clean technology, resource efficiency, circular economy and bioeconomy. The authorities in charge of GPP policies include the Ministry of the Environment, the Ministry of Economic Affairs and Employment and the Ministry of Finance. A government decisionin-principle on the promotion of sustainable environmental and energy solutions (cleantech solutions) in public procurement was published on 13 June 2013, which states that in all government procurements, the goal is a comprehensive solution that promotes energy and environmental goals and utilises cleantech solutions in the most economically advantageous way. Although there is no explicit reference to the circular economy in the document, specific attention is paid to sectors such as food and catering, vehicles and transport, construction, energy, services and energy-related products (Finnish Government, 2013).

In addition, Motiva - the Focal Point for Sustainable and Innovative Public Procurement - provides advice and consultancy to public procurers about sustainable and cleantech procurements, covering all stages of the procurement process. Motiva operates the sustainable and cleantech public procurement helpdesk in Finland, and national GPP criteria had been developed for seventeen product groups by $2016 .{ }^{6}$ These include GPP criteria for food and catering, vehicles and transport, construction, energy services, energy-related products and textiles (workwear). Motiva provides information also about circular procurement.

In Finland, cities and municipalities have set their own strategies, in which the circular economy is one pillar. This will increasingly be implemented in their procure-

\footnotetext{
4 http://rejseholdforgrønneindkøb.dk/da/hvilken-raadgivning-kan-i-faa/raadgivningspakker/cirkulaer-oekonomi (only available in Danish)

5 http://www.cradlepeople.dk/english/

${ }^{6}$ http://www.motivanhankintapalvelu.fi/tietopankki
} 
ment strategies and programmes in the near future. Circular investments and procurement is seen as important in the municipalities' strategies due to the fact that the public sector can, through circular procurement and investments, reach their environmental targets, gain financial benefits, and increase business and employment. The strategies do not, however, always explicitly state circular procurement but rather include circular economy objectives into the broader climate mitigation target. In the strategies, investments in infrastructure and building construction are referred to as a means to increase the reuse and recyclability of materials, and as a reference to the circular economy in the municipality. In addition, many pilot projects that aim at improved circularity of materials and resources have been undertaken in the fields of construction, biogas and catering (for more information, see Chapter 7).

Generally, in Finland, it is expected that circular procurement is implemented to a certain extent. In the analyses of national GPP criteria, several criteria exist that support circular elements (Chapter 6). However, there is no data on to what extent procurers actually use these criteria in their procurement. Based on inquiries into several procurement units in Finland, circular criteria in procurement have generally focused on requirements or inquiries about the use of recyclable materials, requirements on the recyclability or reuse of packaging materials, and non-use of PVC materials.

According to the screening of available calls for tender in HILMA, the national tender database (August 2016), only a few calls for tender were found in which circular criteria could be found. For example, in three out of 22 textile calls for tender, circular requirements were presented. These included criteria such as timelessness, durability, easiness to clean and availability of repair services. With regard to furniture, two out of five calls for tender included some circular requirements, such as long guarantee (five years), collectable and recyclable packing materials, durability of materials, and easy maintainability. Further, in catering services, only one call for tender out of three referred to the circular economy in terms of suitable size of the delivery lots.

In order to make generalisations, a larger sample of calls for tender should be examined. Based on the HILMA screening it can only be concluded that none of the open calls for tender included a novel form of procurement criteria that would actually promote new product development or innovative solutions. Nevertheless, strategies and pilots exist in Finnish cities and municipalities that could serve as good practice for developing circular economy-based models further.

\subsection{Sweden}

The National Agency for Public Procurement (Upphandlingsmyndigheten) is the central agency that is responsible for public procurement in Sweden, including aspects related to the circular economy, suggesting criteria to be used for sustainable procurement for all relevant goods and services. SKL Kommentus is another important agency working in this field, but which focuses more on offering municipalities and county councils framework agreements, including recommended environmental crite- 
ria and follow-up activities. The Swedish Ministry of the Environment is active in the ongoing dialogue on the circular economy on an EU-wide basis.

The National Agency for Public Procurement offers a "criteria wizard", which includes almost 900 suggestions for environmental criteria for all types of goods and services relevant for public procurement. These recommendations for procurement criteria make a distinction between three levels of details and ambition: basic level, advanced level and spearhead level. The National Agency for Public Procurement offers a daily helpdesk service, a tool for life cycle costing (LCC), and has established a national network (Thinktank) for innovation procurement.

The initiative taken by the Swedish government to make suggestions for environmental criteria for public procurement has led to a situation whereby the majority of public authorities make use of them in their daily work, e.g. all county councils and some $85 \%$ of all municipalities (Figure 2). Therefore, a survey of the Swedish conditions with regard to circular procurement has to focus on the criteria set out by the National Agency for Public Procurement. An overview of product categories and groups with associated criteria types is presented in Appendix 1.

Figure 2: Use rates of environmental public procurement criteria in Swedish public procurement units

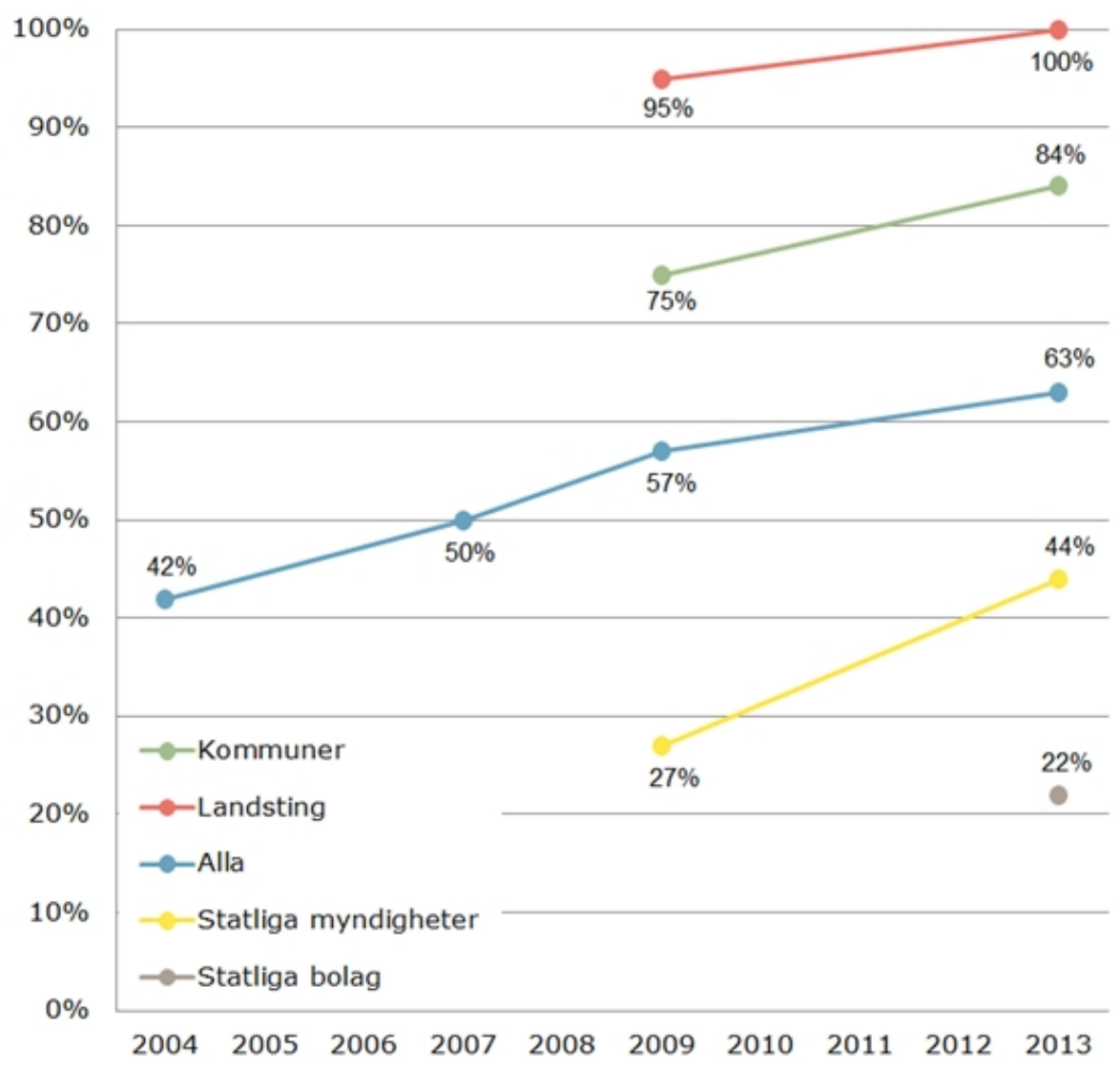

Source: Ryding, 2012. 
In Sweden, a group of 25 municipalities has set ambitious goals for sustainable development. They are referred to as "eco-municipalities" and are considered to be forerunners in a number of sustainability aspects and green public procurement. Some county councils have established networks among themselves and collaborate in setting criteria, some of which is fairly advanced. They also include social criteria in the tendering process, as well as online systems for follow-up procedures.

In Sweden, quite a number of consultancy firms exist which offer their services with regard to sustainable procurement. However, it is most likely that only a few of them currently have the right and updated competence to be able to extend their services to circular procurement. 



\section{Aspects of circular procurement - a method for criteria analysis and case selection}

A prepared list of circular elements was used to search for circular criteria in eco-labels and procurement criteria, as well as mapping the potential circular procurement cases.

In the analysis of eco-labels and procurement criteria, four categories that are considered to be the main aspects of circular procurement in this study were examined in the existing eco-label and procurement criteria:

1. Extended product lifespan.

2. Efficiency and/or intensity of use.

3. Cycling of biological or technical materials.

4. Clean and non-risky cycles.

These four aspects were also used as a basis for analysing the selected best practices of circular procurement (Figure 3). However, in finding and selecting the cases, the aspects were modified and opened up in order to capture the best practice cases more effectively. The selection of cases was based on the following categories/criteria:

1. The procurement process in general is focused on circular aspects; i.e. in the description or objectives of the procurement.

For example:

- The subject matter is defined as being respective to circular economy (e.g. procurement of textiles of recycled materials).

- The supplier is asked for a new solution, or the description of the subject matter is "open" to innovative solutions that stimulate the circular economy and related business.

- A description of circular processes are asked for/required in the tendering phase, e.g. the supplier should describe how the materials are to be circulated, what the end product is and what are its markets, etc.

2. Extended product lifespan and efficient use were focused on in the procurement. For example:

- Shared use is procured or supported, i.e. car sharing.

- Reuse of products, parts or materials is required. 
- A long guarantee is required or the length of guarantee is awarded.

- Availability of spare parts is required (after the guarantee).

- A leasing concept is used.

3. Cycling of biological or technical materials are focused on in the procurement process.

For example:

- Requirements are presented for using recycled materials in the product or a certain fraction.

- Requirements are presented for recycled packaging.

- Requirements are presented for utilising (nearby) secondary material flows or by-products.

- Requirements are presented for recyclability of the products, parts or fractions.

- Requirements are presented for recyclability of packages (with regard to materials to which a recycling system exists).

- The European waste hierarchy (which favours material recycling over energy recovery) is supported in the procurement.

4. Clean and non-risky cycles are paid attention to in the procurement process.

For example:

- Requirements for the use of non-toxic chemicals are presented.

- Requirements for the disposal of materials or parts are presented.

5. Certain tools are used in the procurement process to address circular elements.

For example:

- Life cycle costing (LCC) is used as a basis for cost calculation.

- Eco-label criteria or Green Public Procurement (GPP) criteria that support recycling, reuse, recyclability, non-toxicity, etc. are used.

- Eco-design is paid attention to. 
Figure 3: Closing the loops through circular procurement

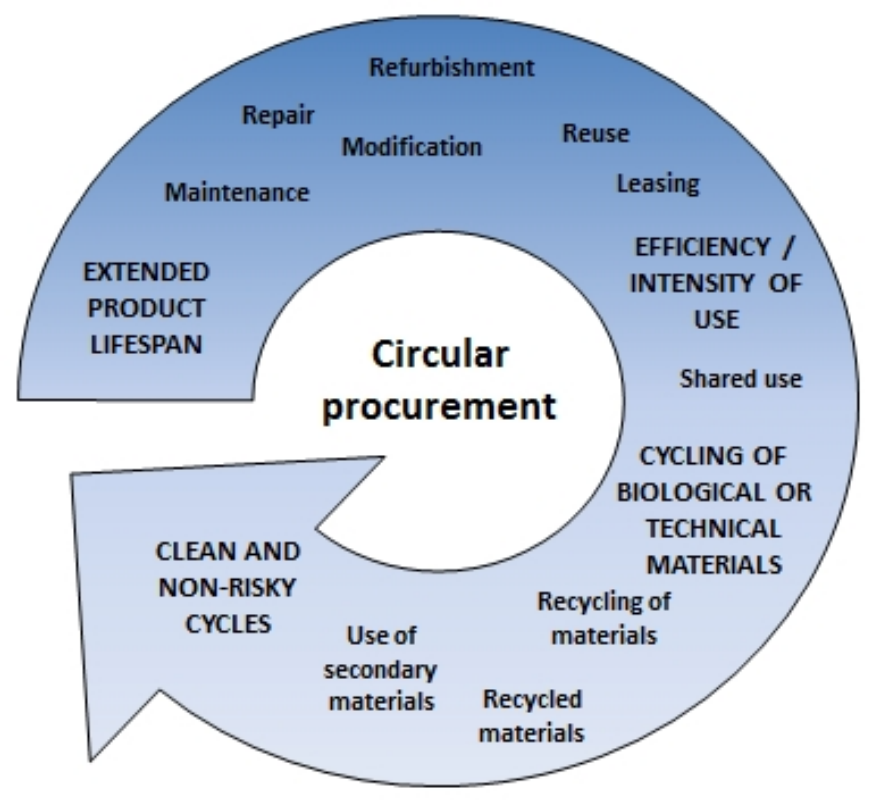





\section{Analysis of criteria promoting circular procurement}

\subsection{Eco-labels}

A growing number of procurements are using the Nordic Ecolabelling criteria as environmental requirements and the Nordic Ecolabel licence as documentation that the requirements have been met. In general, the Nordic Ecolabel pays attention to the environmental and health impacts along the whole life cycle of the product or service.

A Nordic study (Suikkanen \& Nissinen, 2016) on the role of the Nordic Swan Ecolabel criteria in steering towards the circular economy divides the circular criteria into four sections: product design, production process (including raw materials), consumption and waste management. In each category there are different kinds of opportunities to promote the circular economy. According to the study, the currently valid criteria documents contain requirements on promoting the circulation of materials: recyclability, non-toxic cycles, recycled content (use of recycled materials), and recycling in production and at end-of-life.

Suikkanen and Nissinen (2016) also point out that recyclability can be limited by hazardous chemicals, and their recirculation in the recycling process would need to be known. The currently valid criteria promote the extension of product lifetime through a focus on durability. To a limited extent, multi-functionality and modularity for repair and upgrade have also been considered.

From the perspective of the circular economy, more possible criteria probably exist. There could be more requirements on reuse and the use of recycled materials. There are no criteria for the recovery of critical raw materials in EEE. It also seems that in certain product groups, criteria supporting the circular economy are more common and have greater potential.

The use of eco-labels in procurement may involve challenges. In some product groups, e.g. textiles and clothing, a large amount of different eco and other labels exist that are used in varied ways and to a greater and lesser extent. This can weaken the opportunities of circular economy products to enter the markets if they are for some reason marked with other than eco-labels.

\subsection{EU GPP criteria}

The EU Green Public Procurement (GPP) criteria have been developed for 21 product groups to help procurers include and verify green requirements in public tender documents. While including criteria for good environmental performance, these criteria 
also support the circular elements of procurement. Product groups such as cleaning products and services, textiles, food and catering, furniture, copying paper and ICT devices as well as other electronic devices in particular include criteria that focus on circular elements.

As a general criterion for all product groups, the importance of appropriate education about the correct and resource-efficient use of products and materials is seen as important. In addition, for the construction and maintenance of buildings, competence in design, specification and site management are paid attention to in order to minimise construction and demolition waste and to use building products or materials with a high recycled or reused content. Site management competence also requires knowledge on off-site treatment options.

Several GPP criteria support the extension of life span and/or efficiency of use. These include the use of reusable packages or reusable parts in devices, cleaning clothes and cutlery. In addition, it is advised to include repair and the right to exchange parts/products in guarantees. Spare parts must also be available for five years after the guarantee period. Particularly in the furniture product group, durability, easy to assemble/dissemble and recyclability are mentioned.

Most of the "circular criteria" focus on facilitating recyclability or the recycled content of products. Criteria about the use of recycled material in packaging (such as being made of $80 \%$ recycled materials), products made of $100 \%$ or $75 \%$ recycled material (paper products) or products that should be fully or partly made of recycled material (furniture) are commonly used.

In addition, non-risky cycles are paid attention to in criteria such as the avoidance or limitations of certain chemicals, e.g. phosphorous and biocides in cleaning detergents, solvents in furniture, and TCF chemicals in paper production process.

The EU GPP criteria give examples of criteria that support the circular economy. They may not, however, be directly applicable at the national level, due to different market conditions and the availability of products, but these criteria can provide a basis for the creation of national GPP criteria, i.e. Motiva in Finland and NAPP in Sweden. The next chapter discusses these national criteria and their circular focus.

\subsection{National procurement criteria supporting circular aspects}

In Sweden, criteria for public procurement offered by the Swedish Agency for Public Procurement for over 50 products groups are suggested at basic, advanced and spearhead criteria levels. Among the spearhead criteria, it is possible to find criteria that promote circular economy.

As a general observation, there are only a few criteria focusing directly on the concept of a circular life cycle approach instead of a linear one. Examples can be found in the IT sector, buildings and real estate, and vehicles and transportation. (See NAPP criteria in Appendix 1.)

In Finland, Motiva is constantly working on national GPP criteria and at the moment those criteria exist for seventeen product groups. Criteria have been developed 
in co-operation with stakeholders. Table 2 illustrates several examples of Motiva's criteria that promote the circular economy.

Table 2: Examples of procurement criteria supporting the circular economy and their applicability for product groups (by Motiva)

Extended product life span:

Reusable packages (many product groups).

Peripherals that extend life span (e.g. engine heater for vehicles).

Long guarantee (many product groups).

Availability of repair, service (many product groups).

Availability of spare parts (three years after the end of manufacturing) (e.g. vehicles).

Efficiency of use:

Advising customers to self-dose (food \& catering).

Control and feedback over waste amount (food \& catering).

Cycling of biological and technical materials:

Recyclable packages (many product groups)

Recycling advice is given clearly (many product groups).

Plastic parts must be marked for recyclability (e.g. IT devices).

Clean and non-risky cycles:

Advice on how to recycle toners (IT devices, computers).

RoHS directive (2011/65/EC) (IT devices, computers).

No mercury or PVC (IT devices, computers).

Hansel is the Finnish government's central purchasing body. In 2015, the public sector procured over EUR 310 million worth of products and services through Hansel's framework agreements, thus having major potential to contribute to sustainability targets. This includes electricity (EUR 76 million), occupational health care services (EUR 61 million), ICT consulting (EUR 47 million), facility user services (EUR 34 million), computers and peripherals (EUR 32 million), and cars and efficient driving training (EUR 31 million) (Hansel, 2015). Table 3 presents several examples of Hansel's criteria that support circular procurement. 
Table 3: Criteria supporting the circular economy in Hansel's framework agreements

Extended product life span:

Retreaded tyres can be procured (car service, vehicles).

Car hiring and leasing services available (car service, vehicles).

Peripherals available (e.g. engine heater) (car service, vehicles).

Availability of user manual (car service, vehicles).

Supplier organises service and repair according to the service programme (car service, vehicles).

Refurbished spare parts are allowed (ICT, computers, printing).

Five-year guarantee for availability of spare parts (ICT, computers).

Leasing of computers (ICT, computers).

$\mathrm{Q}$ : How will the supplier promote the reuse of ICT devices? (ICT).

Efficiency of use:

Guidance will be given on the efficient use and disposal of products (many product groups).

Part of food products are pre-produced (food and catering).

Items are packed so that they will not be damaged during delivery (food and catering).

Cycling of biological and technical materials:

Appropriate disposal of parts and products (car service, vehicles).

Supplier must recycle packaging accordingly (many product groups).

Q: How will the supplier recycle and reduce packaging material? (many product groups).

Packaging material must be marked and easily separable and recyclable (e.g. catering).

Supplier will collect all 100\% recyclable packages (many product groups).

Clean and non-risky cycles:

Q: How has the supplier organised recovery of harmful chemicals? (car service, vehicles).

Cardboard used for packaging must be $50 \%$ recycled material (ICT and many product groups)

Printers must comply with paper made of recycled fibre (8o g) (printers).

Q: How will the supplier minimise waste? (many product groups).

End of waste cannot be located outside the EU (ICT, computers). 


\section{Circular procurement cases}

The Nordic cases illustrate the possibilities of procurement to promote the circular economy. This chapter presents some good examples of such cases, giving a short description and justification for being "circular". The cases illustrate how circular aspects were taken into account in the procurement process (Figure 4). They will also show, wherever possible, the environmental and economic benefit of circular elements. In practice, best practice cases were not found in all sectors, thus "an ideal case" is presented for some product groups in order to illustrate the possibilities of public procuremen

Figure 4: Framework for assessing case studies

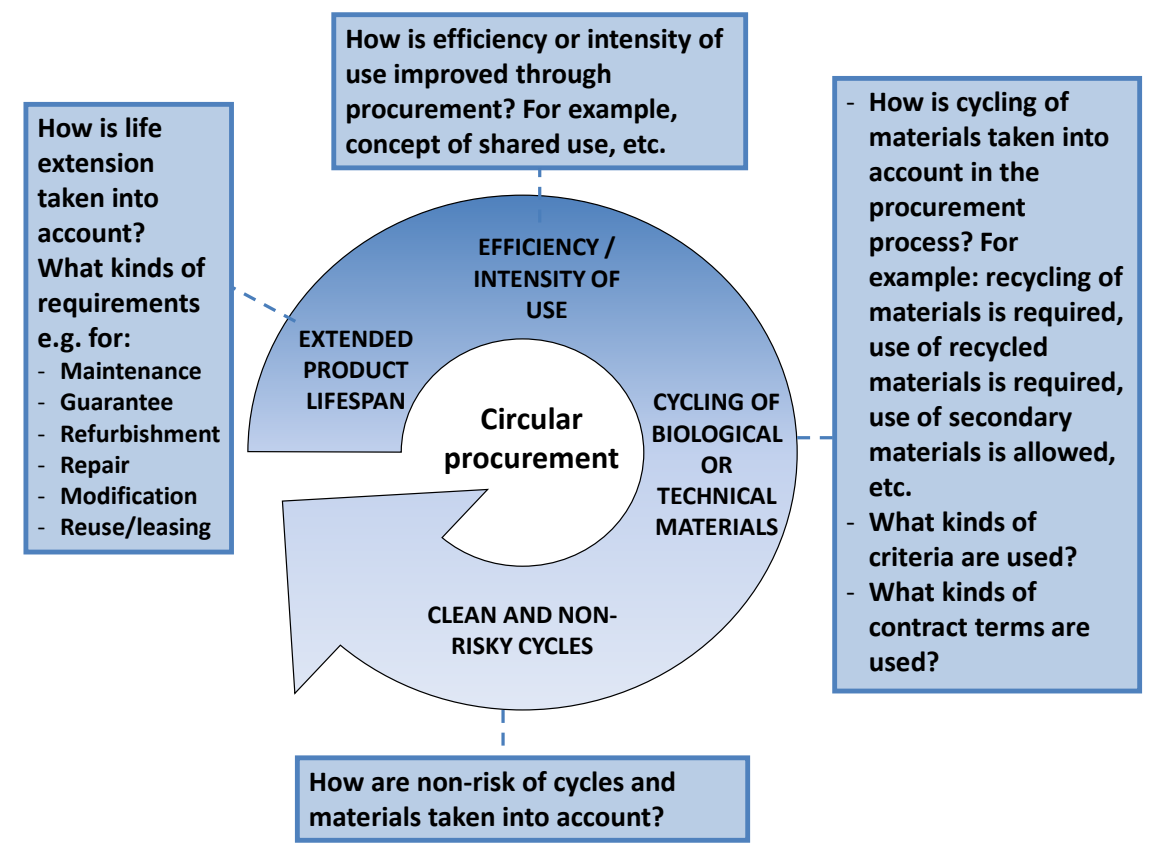

$\mathrm{t}$ in promoting the circular economy.

\subsection{Circular procurement as a strategic tool}

Implementing circular procurement is a strategic matter. An understanding of the cooperation between different functions and departments of municipalities and public procurement units is crucial. For example, the City of Oslo has launched a strategy in which more sustainable consumption and reuse of materials are in focus. This includes 
the efficient reduction and recycling of waste as well as more sustainable food chains, such as $50 \%$ use of eco-labelled food and beverages.

In the strategy to reduce consumption in Oslo, the aim is to reduce municipal material consumption and to increase Oslo citizens' awareness of their own material consumption. The city has developed measures to improve sharing, minimise consumption through public procurement, create more venues for reuse and recycling, and encourage less waste of food.

The main ideas for public procurement include better identification of "need" instead of solutions, evaluation of quality and long-term perspective, identification of material reuse instead of disposal, and criteria for minimising packaging.

An example of implementing the strategy is the "Reusing with care" programme, which is a collaboration agreement on the reuse of furniture and ICT equipment that is meant for all agencies within the municipality. One positive outcome has been the emergence of two different employment training providers (ETP) and the promotion of second-hand use, less waste and less consumption (Karlstad, 2016).

\subsection{Construction}

\subsubsection{Buildings}

Use of old bricks in new buildings

(Copenhagen Municipality, 2011-2013)

General background: The reuse of old building and construction materials has increased since the 1980s, when landfilling became more expensive due to the introduction of a high state tax on landfilling in Denmark. A few years ago a company, Gamle Mursten, ${ }^{7}$ started to clean and sell old bricks from demolition sites, and demonstrated through LCA that using old bricks was a better and longer-lasting solution from an environmental point of view. Furthermore, the patina of old bricks has become popular among architects.

Copenhagen decided to include old bricks into two building projects, including pilot cases extending and renovating old schools. In both cases old bricks were taken from old hospital buildings, which were demolished carefully in order to save as many whole bricks as possible. After demolition, the bricks were sent for cleaning in order to be used again.

7 "Old Bricks", http://en.gamlemursten.dk/about-gamle-mursten/ 


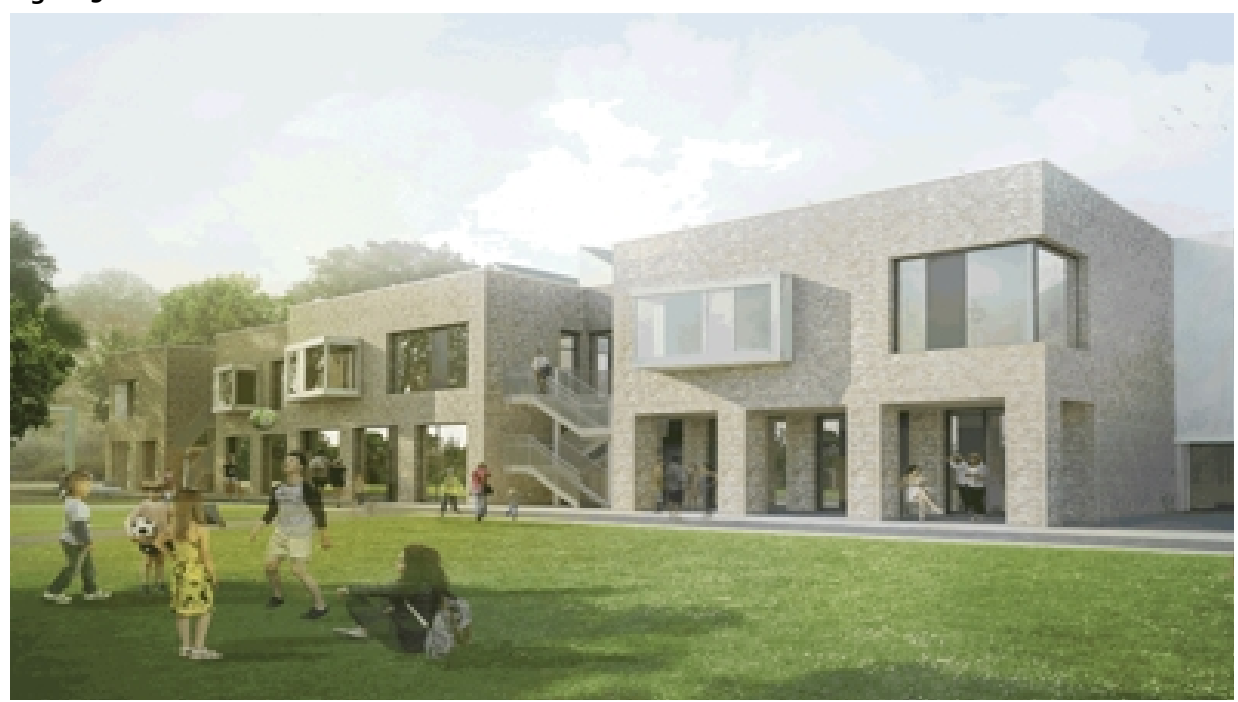

Source: JJW Akitekter A/S.

Success factors: The requirement of using old bricks was clearly specified in the tender document, which stated that bricks for the outer walls should be reused bricks from demolition.

The case showed that it is possible to include a requirement for "reused materials/products" in the procurement documents, even if "the cheapest offer" practice may have previously dominated. These experiences have been developed further into more general rules for environmental criteria for procurement within building and construction.

The demolition and building processes are followed by a group of experts that collect and further disseminate the experiences. The group consists of representatives from Copenhagen Environmental Department, a demolition entrepreneur and the recycling company, the Danish Technological Institute and two consultancy companies.

Impact of the procurement: The reuse of old bricks in new buildings should be compared with their alternative uses, such as crushed materials for road construction. As both applications have a long lifespan, it is difficult to say which application results to the longest lifespan. However, the reuse of old bricks in new buildings provides an opportunity to use the bricks over again as a more valuable product than crushed bricks for stabilising materials under roads.

It is estimated that the reuse of one brick reduces greenhouse gas emissions by $0.5 \mathrm{~kg} \mathrm{CO} 2$ equivalent on average. The reuse of bricks in Katrinedals Skole results in a total reduction of 70 tonnes of $\mathrm{CO}_{2}$ emissions. It is estimated that there is a potential for reusing 30 million bricks in Denmark per year, which can result in a reduction of 15,000 tonnes of $\mathrm{CO}_{2}$ emission per year.

Currently, reused bricks are more expensive than new bricks, but the reused bricks are expected to last longer, which is supposed to compensate for the price difference. Ultimately it is a matter of adopting a life cycle costing approach. 


\section{Environmental Criteria for Building and Construction Projects}

(Copenhagen Municipality, 2016)

The use of old bricks has been supported by the Danish Environmental Protection Agency, which in 2012 initiated a project on the life cycle assessment of the reuse of old bricks. ${ }^{8}$ This can also be applied when incorporating the requirements in procurement documents.

In 2016, the City Council of Copenhagen issued a number of environmental criteria for public building and construction projects, "Miljø I Byggeri og Anlæg 2016" (MBA2016). The MBA2016 consists of a range of environmental criteria that have been targeted at different kinds of building and construction projects, such as:

- Municipal building projects (schools, kindergartens, administrative building, clinics, cultural buildings, etc.).

- Municipal construction projects (roads, squares, etc.).

- Handicraft services, social residential houses.

- Renovation of city space, back gardens.

The MBA2016 includes procurement criteria for resource efficiency, recycling and reuse of materials. The criteria that promote recycling and reuse require a life cycle assessment (LCA) for different materials to be conducted. Those municipal departments planning a building project will need to include at least two alternative materials for each building part when doing the LCA. The department needs to choose the constructions with the lowest negative environmental impact.

For some types of materials there have been a long tradition for reuse/recycling. For example, cobblestones have always been reused for road construction and within the last few decades, procedures for the recycling of tarmac have been introduced as a standard procedure for road construction and road renovation. There are storage options for these materials, and the City of Copenhagen has, as part of their efforts to recycle more materials, expanded these sites.

The MBA2016 is expected to lead to more recycling/reuse of building materials, and more efficient use of energy resources. So far there are no documented experiences on environmental impact and cost efficiency after the introduction of MBA2016. However, the pilot projects conducted ahead of the MBA2016 indicate that there is a potential for environmental benefits and maybe also cost savings, in particular, if the full life cycle costing is taken into consideration.

${ }^{8}$ LCA of reuse of bricks, Miljøprojekt nr. 1512, Miljøstyrelsen, Danish EPA, 2013. 


\subsubsection{Infrastructure}

Recycled materials in road construction

(Case Tarpaper Recycling and the City of Lahti, 2015)

Lahti's procurement strategy aims to support the generation of new business innovations in a circular economy regarding waste and energy procurement. The Tarpaper case represents a pre-commercial procurement in which the city offered pilot areas up for testing recycled asphalt. The aim was to make the use of the roofing felt waste as material in road construction as a normal procedure in the future. In the testing phase the city also developed guidance for circular procurement.

Tarpaper Recycling Finland ${ }^{9}$ has a new patent-registered method for the recycling of roofing felt waste. The sorted roofing felt waste from demolition or refurbishing is processed at the Tarpaper Recycling factory and the material can be used for asphalt production. The processed material is added as a bitumen source in the production of new asphalt. This contributes to a better environment and reduces $\mathrm{CO}_{2}$ emissions. Alongside the strengthening of testing activities of the business of Tarpaper Finland, new investments in technology were made and a functioning collection system for all roofing felt waste generated in Finland was established. Good experiences have been achieved in terms of quality of asphalt as well as availability of roof felt waste. The role of procurers has been significant in accelerating the industrial symbiosis of roofing felt waste as a material for asphalt.

Other initiatives for using recycled materials in road construction can also be found. The Finnish Transport Agency aimed to utilise soil and ash in a pilot road construction project. They set up a bonus system for the tender competition, and as an outcome, a new combination of used material and ash was found and developed, as a result of which the carbon footprint was reduced by 20,000 tonnes (Hankintamappi, 2015a).

Recycled materials were also used in soil construction in the case of Ida Aalberg Park, Helsinki. In the reconstruction of the park, used soil extracted from other construction sites was utilised as much as possible. A significant amounts of money was saved due to the short transportation distances and the reduced need to purchase soil. In addition, the acidity and the microbe population in the used soil were already settled at the right level (Stara, 2014).

9 http://www.tarpaper.fi/Receiving-Places 


\subsection{Waste and waste water management}

\subsubsection{Waste management}

Collection and transportation of household waste in an efficient and environmentally sound manner to a central waste storage site

(VA SYD, Sweden, 2017)

Background to the procurement: Reducing waste means less environmental impact, increased resources and energy recovery, and a financial saving in a life cycle context. Waste management covers all the activities and actions required to manage waste, from its inception to final disposal including collection, transport, material and energy recovery, and disposal of waste together with monitoring and regulation.

In Sweden, a new way of procuring waste management has been introduced in municipalities. The new approach encompasses a separation of activities from collection and transportation to reuse and recycling. Dividing waste management contracts into smaller and separate contracts will increase the number of potential suppliers who offer their services, specifically SMEs as entrepreneurs on-site, which in the long term will stimulate local and regional business activities, lower prices and make sitespecific adaptions possible, to the benefit of the environment.

This case on waste collection is an example of an approach where VA SYD decided to procure waste collection as a separate activity as part of a full waste management strategy. It is becoming more frequent to include a social dimension as a part of the procurement requirements.

The procurement procedure: The procurement procedure was carried out as an "open procurement procedure" and several environmental criteria and requirements were used:

- A certified environment management system must be in place.

- Various measures to stimulate ECO-driving and parking in warm garages to avoid "cold-starting" of vehicles and other equipment.

The following types of "social criteria" with regard to work environment and traffic security were used:

- Work environment conditions in place according to AFS 2015:4.

- Actions programmes for handling communication via mobile telephones (with no hands-free mode) in a secure manner.

- $\quad$ Rules for using alcohol lock devices.

Impact in the region and on future circular procurement: The supplier focused on "upstream work" to reduce environmental pollutants and waste at source, thereby minimising environmental degradation in nearby watercourses. 
There are several life cycle phases in the procurement procedure that follow the main principles of circularity. For waste management, the most critical one is often referred to as the "upstream processes" to secure strict compliance with requirements for collecting different types of sorted waste in separate containers to guarantee as many "clean fractions" as possible. If this is not handled in the proper way, there is a risk that waste may get mixed, which will seriously hamper the efficiency of the "downstream processes" for the recycling and reuse of materials and energy. It is also important to temporarily store waste containers in a secure place, thus awaiting the next phase in waste management. Therefore, the waste collector contractor was requested to transport the containers to a special central storage site for further handling and to avoid any type of leakages and pollution into the outside environment.

From an environmental point of view, it is equally important to store all waste at one waste collection site as it is to facilitate future logistic solutions when the separated fractions of the waste is transported to special plants for material and energy recovery or to a waste disposal site. Local waste storage will ensure that transport to such places can be carried out in an environmentally efficient manner by means of fully loaded transportation modes, thus minimising air pollution and noise.

It is of course of vital importance that the right type of waste has been disposed of and separated in an orderly manner in specific containers in accordance with waste separation instructions. Here the contractor has a special responsibility to inform households about the rules they need to follow for separating the waste.

\section{Multilocker waste collection system}

(Eastern Uusimaa, Porvoo, Finland, 2013)

The waste management company Itä-Uudenmaan jätehuolto (IUJ) tested a multilocker waste collection system in Eastern Uusimaa before actual procurement. ${ }^{10}$ This gave a good insight into the practices and market opportunities, and helped define the procurement criteria. Prior to the procurement, a household survey was carried out in order to identify their level of willingness to pay for the service. This provided information on the cost level in relation to a certain amount of potential customers.

In the multilocker collection system, the mixed waste bin was replaced by a waste bin with four lockers. There were lockers for mixed waste, cardboard, paper, and glass and metal together, which were separated later on mechanically. Mixed waste ended up in energy recovery and the other waste fractions were delivered to further recycling.

Due to the thorough market dialogue, the procurer was able to define the technical specifications in detail, which allowed competition on the cost of the service. Requirements for equipment included emission level, for example. The contract period was 1.5 years.

Significant savings were gained due to more efficient recycling rates. The collected amount of recycled waste doubled compared to the ordinary waste collection system (mixed waste and bring sites). $\mathrm{CO}_{2}$ emissions from transportation were not significantly reduced because the service did not cover all households in the area - only

${ }^{10}$ http://www.rosknroll.fi/ 
those who voluntarily ordered it. Therefore, there were two parallel collection systems working in the area.

The procurement indicated that there could also have been criteria in the tendering process that would have made it possible to alter some technical features, e.g. add a new waste component.

\subsubsection{Waste water treatment}

Procuring pilots of new waste water treatment technology

(Helsinki region, 2016 onwards)

HSY, the Helsinki Region Environmental Services Authority, is undertaking the procurement of 4-5 pilots of new technologies, which will be tested on-site. The objective is to test and evaluate new methods of treating and utilising digested sewage sludge and other biomass at the waste treatment centre in Espoo, Finland. The solutions put forward for testing must comply with the European waste hierarchy and thus favour nutrient and material recycling over energy recovery. The procurer is especially interested in methods that produce fertilisers or biochar (Figure 6).

The procurement case enables the development of new innovations in the preprocurement phase. Through a market enquiry, the procurer is requesting proposals that describe the end product as well as the markets for it, along with the operational costs of the process. The suggested solution does not need to cover the whole chain from feed to end product. Instead, the value chain can be built in co-operation with several parties. The final procurement will take place after piloting, but not until 2017-2018 (HILMA, 2016). 


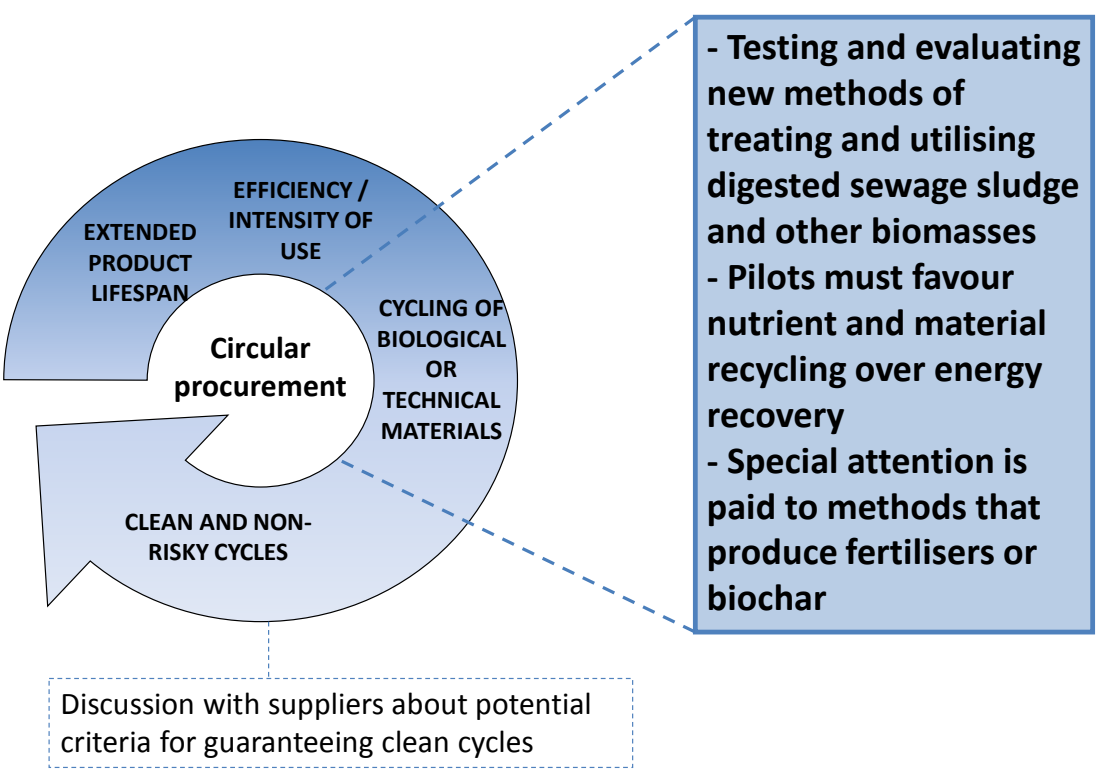

Service for biowaste and sewage sludge treatment

(City of Porvoo, Finland, 2014)

The aim of the procurement was to improve the recycling and reuse of phosphorus and nitrogen. The recycling of nutrients was included in the procurement process of the treatment of sewage sludge and biowaste for the first time in Finland.

Description: The circular aspect of the procurement was to improve the recycling and reuse of phosphorus and nitrogen through the treatment service. The procurement was undertaken as a joint procurement of several waterworks facilities and biowaste management facilities. The annual volume of the service was 24,500 tonnes of sewage sludge and 6,000 tonnes of biowaste.

Circular aspects in the procurement process: The cycling of nutrients was included in the definition and objectives of the procurement. Prior to the formal call for tender, a request for information was sent through HILMA, the national tender database, in which potential suppliers were informed about the requirement to recycle nutrients. Potential suppliers were also invited to discuss their views about the requirement.

Procurement processs: A competitive procedure, i.e. negotiation, was used as a procurement procedure. This enabled the discussion about circular aspects, and the recycling and end use of nutrients in particular. The procurer requested that the potential suppliers provide a description of how the aspects regarding energy efficiency and the cycling of nitrogen and phosphorus would be processed and optimised during the service. Possibilities for the location of the end product were also requested. 
Outcomes: As a result of the negotiations, several technical criteria were stipulated in the final call for tender, stating that a minimum of $80 \%$ of the nitrogen delivered to the treatment plant must be directed to be used as a fertiliser product or industry chemical, and only $20 \%$ may end up in the local waste water treatment plant.

Lessons learnt: The linking of circular aspects to the treatment service of biowaste and sewage sludge was challenging due to the fact that the constitution of the primary product that enters the treatment plant is heterogeneous and the concentration of harmful substances is not well known, as it varies over the seasons. In addition, comparability of the recyclable aspects in the tendering phase was not an easy task, as a result of which the supplier ended up setting mandatory requirements concerning the share of nutrients to be recycled. In addition, substantial sanctions were set in case the supplier did not follow their commitments during the contract period.

Market response or availability of solutions: The innovation in this procurement was the process. The recycling of nutrients was included in the procurement process of the treatment of sewage sludge and biowaste for the first time. However, no new technology was developed in the procurement.

Impact on the circular economy: This case contributes to the circular economy in particular in terms of the cycling of materials as well as confirming clean and non-risky cycles. This was achieved by setting mandatory criteria concerning minimum levels of recycling of phosphorous and nitrogen. Substantial financial savings have been reported. These savings are, however, mainly due to the high volume of primary products and the joint procurement of the service.

\subsection{Transportation}

\subsubsection{Public transportation (all types) including city and regional transport modes, and specific service transportation}

(Kalmar Länstrafik, Kalmar County Council, Sweden - 2017)

General information about the procurement procedure: The procurement followed a negotiated procedure including bidders qualified via pre-qualification. The following criteria and requirements were used:

- Enhanced use of biofuels and electricity to reduce $\mathrm{CO}_{2}$ emissions.

- Requirements for a gradual reduction of emissions of NOx and particles during the contract period.

- Measures for noise limitations.

- Requirements on high energy efficiency.

- Certified environmental management systems in place.

- Regular follow-up procedures and annual environmental reporting. 
Impact on the region and the circular economy: In the Kalmar region, the "circular procurement criteria" included strict requirements for replacing fossil fuels with different types of biofuels (biogas, sustainable synthetic diesel, "green electricity", RME and ethanol) including electricity. This was meant to simulate a higher generation and production of these fuels and electricity from local or regional activities and manufacturing to successively reduce net $\mathrm{CO}_{2}$ emissions compared to the use of fossil fuels. In order to highlight other types of fuels and electricity providing a $50 \%$ reduction or more of emissions of greenhouse gases compared to fossil fuels, the tender document included a list of different types of alternative sources such as ethanol, biodiesel, vegetable oil, biogas from municipal waste or liquid and solid manure, as well as "green electricity" from wind, water, biomass or solar sources.

Another vital component of the procurement requirement was the strict follow-up and regular reporting procedure to facilitate monitoring of the reduced emissions of NOx and particles and the enhanced use of renewable energy sources and fuels to minimise emissions of greenhouse gases. Annual reporting on the fulfilment of meeting the procurement requirement will make it easy for the procurement authority to check compliance with the set rules. It also enables the procurement authority to implement supplementary measures in case the supplier has difficulties in meeting the procurement requirements.

\section{Biogas buses in public transportation}

(City of Vaasa, Finland, 2014)

Another example of circular procurement in public transportation is the use of vehicles run by a locally produced biogas. Buses that use locally produced biogas were implemented as part of public transportation in the City of Vaasa. The city organised two separate tender competitions 1) for the service provider and 2) for the biogas vehicles, including their maintenance. The City of Vaasa committed to buying twelve biogas buses and to release them to the use of the service provider, who in turn has committed to take these vehicles into use for the next five years. This helps transfer the business risk from the service provider to the procurer. In addition, the city made a contract with a local biogas producer, Stormossen, who in turn organised the biogas delivery network tendering.

As an outcome, a new business ecosystem was developed that includes the more efficient utilisation of waste and biogas production from local waste. There was also an aim to expand the biogas network to the private market. Expected savings for the biogas buses amounted to 1,000 tonnes of $\mathrm{CO}_{2}$ per year.

The procurement was successful due to the fact that a market research study into the possibilities of local biogas production and its utilisation was undertaken before the procurement. The study showed that the compact city structure of Vaasa was suitable for efficient emission reductions. A key to the success of the procurement was the procurement of vehicles by the public authority (not by the service supplier). Another major success factor was the committed group of people throughout the project (Hankintamappi, 2015b). 


\subsection{Food and catering}

The circular economy regarding the food system implies reducing the amount of waste generated in the food system, reuse of food, utilisation of by-products and food waste, and nutrient recycling. The measures must be implemented both at the producer and consumer levels, and finally in food waste and surplus management (Jurgilevich et al., 2015). Several possibilities also exist in public procurement.

In Finland, the utilisation of fish stock management was piloted by the Pyhäjärvi "roach project". Formerly, around 230,000 kilograms of roach had been harvested due to management of the fish stocks, and most of this amount had ended up as waste or animal food. In the project, a new product was created using roach as a source of fish steaks, targeted to food services for private as well as public consumers. New product development increased the added value of the roach as it had previously been considered more as a "waste fish" rather than food. This also provided new business opportunities for local fishers and businesses. In addition, the conditions of Pyhäjärvi improved and eutrophication decreased as a result of the roach harvesting (PapeMustonen, 2015).

Another example comes from the Finnish municipality of Sodankylä, where continuous improvements in the resource efficiency of food chains have been taking place for several years. The procurement function pays attention to how products and raw materials enter the stock, how they will be handled and processed, packed and delivered. In addition, seasonal food opportunities, local production and co-operation, logistics, experiments and product development as well as innovative recipes are included in the overall planning of circular food procurement. Attention is paid to how to most effectively process different food and raw materials in the kitchen instead of ordering pre-processed food products.

Technological applications have helped in timely deliveries and processing of the food. For example, cooking at night and freezing unused food are possible due to technological solutions. The new central kitchen is "a small-scale food factory" which allows for the processing of components. This reduces the need for daily deliveries and the amount of waste food. Biowaste is reduced, partly because the food can be semi-finished and frozen before the final cooking stage. Also, the sizes of the ordered lots are carefully considered in the procurement phase.

\subsection{Furniture}

\subsubsection{Rental beds for home hospice care patients}

(City of Helsinki, 2013)

The City of Helsinki tendered the rental of nursing beds instead of procuring the beds. The supplier delivered the beds and mattresses according to the patient's needs. A new product was designed that was easy to transport, fitted through small door- 
ways and into lifts, and opened up into normal use position in a few minutes, using its own motor.

This case is an example of a service business concept in which the supplier offers the most comprehensive service instead of product. The winning bidder, Lojer Oy, gained a market reference for a new product (Lojer, 2014).

Life cycle service for furniture

(Service provider, Isku Oy, Finland)

A furniture manufacturer, Isku Oy, has introduced a life cycle service concept for procurement, which includes planning, financing, delivery, follow-up, maintenance, service and recycling. The idea is to start with planning that addresses the needs of the procurer and allows flexibility for different purposes and spaces. Delivery includes transportation, assembly, service, maintenance and disassembly. In addition, the service will provide measurement of the efficiency of use of furniture and utilisation of space. Recycling is handled accordingly, preferring reuse and recycling of parts (Isku, 2016).

\section{Duba-B8 for Danish municipalities}

(Danish SKI, 2015)

In Denmark, the furniture company Duba became the exclusive supplier for a joint municipal procurement contract. SKI, the Danish state procurement authority, made a contract agreement that requested that all office furniture must be able to be disassembled into parts and be reused several times. Duba-B8 focuses on extending the lifetime of furniture and on recycling. Products must also meet a number of requirements of the Nordic Eco-label criteria for furniture and fixtures, and $70 \%$ of the wood used must be either sustainable or recycled. The supplier also offers a service where technicians maintain, adjust and repair the furniture on-site, as well as a re-entry scheme that ensures that furniture components are correctly recovered in the procurers' premises, recycled, refurbished (metal) and disposed of (Duba-B8, 2016).

When the joint municipal agreement was offered, there was no way around it. Test municipalities assessed the quality of the furniture, and tests were conducted at the Technological Institute. The environmental performance had to be documented through certifications.

The joint municipal procurement contract is expected to provide DKK 200 million in turnover in the next four years, between four and six new jobs have been created as a result of the contract, and a new office chair series is expected to become a successful export product. In addition, Duba-B8 has a marketing advantage due to the ability to prove that they can comply with criteria and demands from the public sector (Danish Ministry of the Environment, 2013).

As concluded from the above, an "ideal" circular procurement of furniture could include the following elements (Figure 7): 
Figure 7: Circular elements in furniture procurement

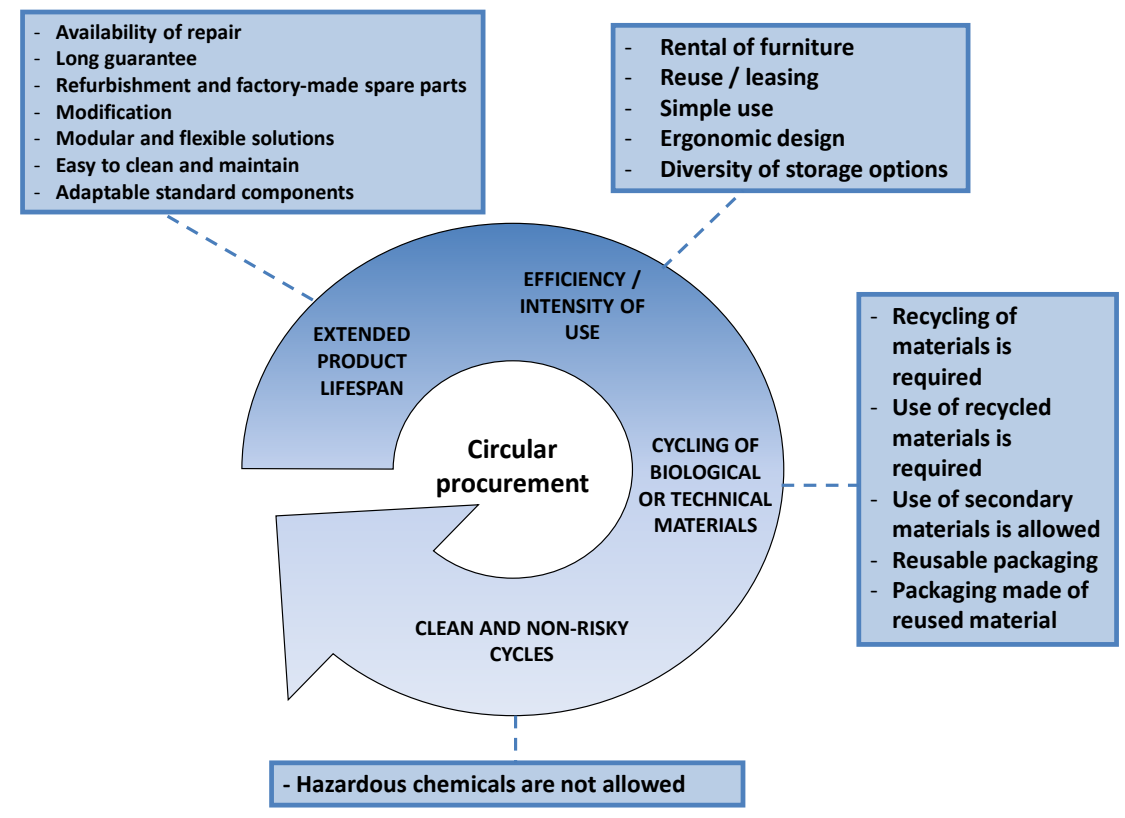

\subsection{Textiles}

\subsubsection{Leasing and recycling of working clothes}

(Herning Municipality, Denmark, 2013-2015)

Background: In 2013 the Municipality of Herning started to prepare a model for a circular economy. Part of the implementation was to increase reuse and recycling. The aim was to extend the lifespan of working clothes, and to ensure that the clothes/materials were used more efficiently. This was done by developing detailed guidance on the criteria for the reuse, repair and disposal of working clothes.

The project started by searching for opportunities to increase the reuse and recycling of working clothes together with the TEKO Design School. Circular principles were introduced to the contractor from whom the clothes were leased. Although many examples of leasing, washing and maintenance of clothes existed, this model of reuse and recycling had not been introduced to procurement before.

Impact of the procurement: It was estimated that savings of 6,700 and 1,011 tonnes of $\mathrm{CO}_{2}$ were achieved over a four-year period in Herning's technical operations department (Hillgrén et al., 2015; updated Herning Municipality). 


\section{Future potential of different product groups}

There are opportunities to promote the circular economy and new business openings in public procurement and investments. This study recognised this potential, especially in the procurement of buildings and infrastructure construction, waste water treatment and public services such as public transportation and waste management. These are also sectors with high annual procurement and investment volumes (Alhola et al., 2016; Alhola \& Nissinen, 2015). In addition, the analysed cases imply that the potential for market creation and business for new products and materials exist in product groups such as textiles and furniture as well as in the utilisation of bio-based products. These views were supported by interviews with industry and business representatives in the fields of construction, waste and waste water management, textiles, furniture and food and catering, as well as with public procurers and persons who have a good insight into the strategy development in cities and municipalities.

\subsection{Construction}

Major potential for circular procurement exists in the construction sector, i.e. infrastructure and buildings. Infrastructure projects may be a significant source of materials, and they may offer potential sites to which material flows from nearby can be delivered and utilised. Technologies already exist that enable the utilisation of used material and secondary flows, although this material may still have a higher initial price compared to conventional options. However, if calculated on a life cycle basis, the price of these materials becomes more competitive.

Cities and municipalities may face several strategic questions on how to implement circular elements in construction, such as, how to organise infrastructure works such as the construction of waste water infrastructure and roads in parallel, so as to minimise waste of resources and maximise the use of material flows. Another question relates to how the construction works could be implemented based on "zero aggregates", i.e. making use of secondary materials and on-site materials, and what kinds of terms of plot leasehold could be set in order to promote circular construction.

This highlights the importance of urban planning and the design of large road and other infrastructure construction projects, including earthworks, ground works, base layers and surfaces, as well as the surrounding areas. Commonly, the cost-efficient option has been the reuse of materials on-site, but due to well organised soil management and real-time information, such as soil information databases, the potential of reused aggregates could be better realised. 
In building construction, circular elements include the reuse and recycling of materials. In addition, the efficient use of room space and multi-purpose buildings provide opportunities for new multifunctional furniture and fixtures, and it reduces the need for more buildings. New market opportunities related to recycled material-based products also arise in the field of building components. For example, ecological wood stone - a stone made of recycled fibres (Destaclean, 2016), biocomposite products for outdoor construction and cladding (UPM Profi, 2016) or other similar products could also be utilised in public buildings and spaces.

\subsection{Waste management}

Waste management practices are not uniform among countries, regions and sectors due the fact that setting up proper and efficient waste handling mechanisms has to respond to site-specific waste problems and be in accordance with local or regional regulations.

Increasing the recycling rate is possible by introducing a multilocker collection system, for example, as a systematic way of collecting waste. Public tendering could create innovative solutions to the collection, transportation and treatment of waste with a certain goal for recycling. One challenge is that the responsibility of municipal solid waste management usually belongs to municipalities (in Nordic countries) and they often rely on traditional, tried-and-tested technology and methods. The use of innovative systems can be more expensive and contain uncertainties, which is a threat for a public operator.

For private companies and industry, waste management services offer comprehensive solutions where circular economy aspects can be taken into consideration as far as the customer sees it as meaningful and profitable.

\subsection{Waste water treatment}

Technologies that improve the cycling and intake of nutrients and promote cycling instead of burning are potential concepts that could promote the circular economy. The treatment of municipal waste water and the production of renewable energy through the conversion of waste and residual products into biogas could be applied to procurement in the waste water sector.

\subsection{Food and catering}

Shortening supply chains in order to minimise the disposal of raw material in the food chain could be a profitable approach to improving resource efficiency and circular elements in food and catering services. Another concept is to reduce food waste more efficiently. There is also potential in new protein sources, such as the use of lake fish 
that have previously been considered raw material for animal food. In addition, potential exists at the end of the food chain, i.e. how to reduce the amount of food disposed of by consumers.

\subsection{Public transportation and bio-based energy production}

Lots of potential exists in creating alternative bio-based fuels for public transport and related business ecosystems that enable the production, delivery and consumption of bioenergy. One strategic question is how to optimise the delivery network and what the scale of the target is for the use of bio-based fuels. Indeed, the market for biobased fuels could be expanded to private consumers through public investments as an initiator. Municipalities should also decide how they could support local energy production in coordination with the main energy supply selected.

\subsection{Furniture}

In the furniture business, there is a need to develop life cycle-based services that include planning, maintenance, repair, modification and recycling or reuse. This would lead to the extended life span of furniture. In addition, markets and new business concepts for "products after procurers' use" should be created.

The planning phase is especially emphasised in the procurement process if recycled furniture is used as part of furniture procurement, or if multi-functionality of furniture and fixtures is required. This calls for stakeholder involvement at the beginning of the planning process, such as consulting architects in the procurement planning phase.

In the future, there will be more opportunities to use recycled plastic-based components in manufacturing. The market for furniture components made of recycled materials is developing. Currently, this calls for product development, and according to an industry expert, more such products are expected to be on the market from 2020 onwards.

\subsection{Textiles}

Technologies already exist that enable clothes manufacturing from recycled materials. Likewise, there are fabrics and yarn made of recycled materials on the raw material market. However, as of yet there is not much demand for products made of recycled materials. According to a representative of the textile industry, the best way to promote the circular economy in textile procurements is to choose materials carefully. Materials should be durable, easy to take care of, repairable and free from hazardous substances. These aspects will make efficient use and recycling possible. It is also important to create and adopt means for sorting different textile fibres in waste handling, as this will enable recycling. 
The biggest potential is in textiles from public and private organisations, because of the homogenous quality and sufficient amounts of materials. In order to strengthen the market for recycled textiles and create new business around the use of recycled materials, there has to be a guaranteed supply of raw material. There is also potential for renting workwear instead of owning it in the public sector. This could also create new business.

One suggested potential innovation for procurement could be a material efficient product design. For example, textile procurement could focus on clothes that are produced with the concept of zero waste. This would require detailed product design and cost efficiency examinations. 


\section{Conclusions and the way forward}

Circular public procurement is an element of green and/or sustainable public procurement with the objective of environmental improvements, value creation and social well-being. However, as a distinction from the concepts of green and sustainable public procurement, circular procurement focuses on closed material loops and value retention, i.e. remanufacturing and reusing products and materials several times in a circular manner without causing additional harmful impacts. Elements of circular procurement should not, however, compromise the overall goal of sustainable procurement. As an example, recyclability aims should not be regarded as more important than other sustainability aspects such as greenhouse gas emission targets, or make the life cycle-based price of the procurement non-competitive.

Many governmental and local initiatives that promote green procurement, including sustainability targets, are at the same time promoting circular procurement, although not necessarily explicitly using the term circular procurement. Currently, public procurement supports and promotes the principles of circular economy rather than strictly following the ideal of a circular economy. Although many good cases representing the circular economy can be found, circular procurement has mainly been utilised in the form of pilot cases and it has not yet been systematically implemented to a large extent.

However, a few product groups exist where this is not the case, such as paper, ICT and metal products, for which there are well-developed markets and support systems for recycling. Alongside these product groups there are also some business concepts that have traditionally been based on the key elements of the circular economy. Leasing and renting services related to office equipment, ICT devices or textiles like workwear, mats or restaurant and hotel textiles can bring more intensity to the use of products. At the same time it is a tried-and-tested and profitable business. In these product groups and business concepts, circular elements in procurement are more mature, whereas some product groups and symbioses requiring new business models and co-operation between many stakeholders are only slowly emerging.

One of the reasons why circular procurement patterns and innovative procurement diffusion are slow may be the lack of experience and information among procurement authorities and units in terms of how to carry out an innovative or circular procurement process. It may also be that the procurement authorities have preconceptions about using products that are made of recycled materials, or these products simply do not exist on the market. Thus, public procurers need more information and evidence that these products are as functional and of as good quality as the conventional solutions, or even better. Simultaneously, products and materials connected to recycling must also develop further. 
Procurers need encouragement to engage to a greater extent in innovative circular procurement processes. Some future potential to broaden the use of circular procurement exists. One of the most significant changes from a procurement perspective following the new EU Directive on Public Procurement (Directive 2014/24/EU) is the change connected to criteria-setting, which now is recommended to be based on a life cycle perspective. This means considering the entire product life cycle in a number of activities, particularly highlighting the importance of determining the environmental requirement(s) for the purchase of products and services. Life Cycle Costing (LCC) could be an approach to take secondary materials and the reuse and recyclability of materials into account in public procurement while also making the economic benefits of circular procurement visible.

Another vital component introduced to the market in recent years which will put pressure on market actors to introduce a life cycle perspective in procurement activities is the latest version of the international standard on Environmental Management Systems (ISO 14001), which emphasises the additional focus on a number of requirements, such as increased prominence of environmental management as part of the organisation's strategic planning processes, the addition of proactive initiatives to protect the environment from harm and degradation, and a life cycle perspective when identifying significant environmental aspects, environmental goals, and establishing routines for purchasing.

The increased use of circular procurement also depends on how the conditions in which the procurer operates develop. If an efficient service provider network or aftermarkets exist, circular procurement is more attractive. A more structured overview of related potential suppliers and what the market can offer can be achieved through market analysis. Applying circular procurement is also a question of how the procurer can get relevant information from actors in the supply chain. Procurers could, for example, start to routinely request environmental information throughout the value chain as part of the contract clauses, or secure sufficient resources to carry out follow-up activities to get a better handle on deliverables according to contracts and to secure continuous improvements among suppliers and sub-suppliers. However, not all relevant information can be received through dialogue between procurers and suppliers. There is also a need for objective information providers, e.g. focal points for procurers.

It has been argued that the transition to a functioning circular economy regime requires systemic multi-level change, including technological innovation, new business models, and stakeholder collaboration (Witjes \& Lozano, 2016). When extending life spans and transforming waste into new resources, it is important to understand the opportunities provided by new business models, digitalisation and a regulative framework, i.e. what is considered useless waste and what is considered raw material. One could argue that circular procurement is well applicable to sectors in which the circular economy is being promoted. This may also include eco-design activities, supportive legislative frameworks, circular supportive urban planning and the development of related business activities.

Requiring circular elements in public procurement can lead to substantial reductions in material use and environmental impacts. The supply of such products may still 
be limited in the market and therefore it may be worth proposing these criteria as award criteria instead of requiring them as technical specifications. However, if market potential or opportunities for market creation exist for such products in a relatively short time, they could also be used as mandatory requirements. Criteria must be considered on a case-by-case basis, since the operational environment varies for different procurements.

Overall, a circular economy lays the foundations for developing sustainable cities and regions. It requires strategic thinking at all levels of public decision making as public procurement is one means of implementing the strategic aims of the circular economy. Areal planning is of great importance, especially in terms of infrastructure and building construction, public transportation and the utilisation of local energy production. In addition, procurement strategy is important in the procurement of products and services.

In order to promote circular procurement, procurers will need to establish an ongoing market dialogue with businesses and other actors. It is important to create circular economy-based new businesses and industrial value chains in which more companies are involved, as well as to developed related logistics. Enhancing co-operation and dialogue between target groups in the planning and procurement process could be one of the priority areas nationally and in future Nordic co-operation. The Nordic countries could also become frontrunners in circular procurement and establish common guidelines, as numerous procurement cases promoting the circular economy and a shared interest in this matter already exist. 



\section{References}

Alhola, K. and Nissinen, A., 2015. Exploiting the potential of public procurement - Opportunities for cleantech diffusion. Proceedings of the Global Cleaner Production and Sustainable Consumption conference in 1.-4.11.2015, Spain.

Alhola, K., Saramäki, K., Manninen Kaisa, Lehtoranta, S, Judl J., Pursimo, J., Linjama J., Pietiläinen O-P., Huuhtanen, J. and Tainio, P., 2016. Cleantech in public procurement. (In Finnish): Cleantech julkisissa hankinnoissa. Finnish Environment Institute Reports 10/2016.

Danish Ministry of the Environment, 2013. Green Procurement and Green Products Generate Growth. Environmental Protection Agency

http://www.motivanhankintapalvelu.fi/files/720/Danish_GPP_cases.pdf [www, 12.12.2016].

Destaclean, 2016. The First in Europe: The ecological wood stone.

http://www.destamatic.fi/fi/ajankohtaista/the-first-in-europe-the-ecological [www, 10.12.2016].

Duba-B8, 2016. Quality and Environment. http://dubab8.com/en/about-duba-b8/quality-andenvironment/

Ellen MacArthur Foundation, 2015a. Public Procurement in Denmark.

https://ellenmacarthurfoundation.org/case_studies/public-procurement-in-denmark [www, 22.9.2015]

Ellen MacArthur Foundation, 2015b. Circular Economy. https://ellenmacarthurfoundation.org/circular-economy

European Commission, 2015. Closing the loop - An EU action plan for the Circular Economy, $\operatorname{COM}(2015) 614 / 2$, Brussels.

European Commission, 2014. Towards a circular economy - A zero waste program for Europe, $\operatorname{COM}(2014) 398$ final, Brussels.

Finnish Government, 2013. Government Decision in Principle on the Promotion of Sustainable Environmental and Energy solutions (Cleantech solutions) in Public Procurement.

Green Deal, 2013. Circular Procurement. http://www.circle-economy.com/green-deal-circularprocurement/ [www, 14.1.2016].

Hankintamappi, 2015a. Maamassojen ja sivuainevirtojen hyödyntäminen maarakentamisessa https://wwwp5.ymparisto.fi/hankintamappi/Kohteet/Tiedot.aspx?ld=178 [www, 12.12.2016].

Hankintamappi, 2015b. Biokaasubussit Vaasaan.

https://wwwp5.ymparisto.fi/hankintamappi/Kohteet/Tiedot.aspx?ld=166 [www, 12.12.2016]

Hansel, 2015. Facts and figures. Helsinki.

Hillgrén, A., Bröckl, M. and Halonen, M., 2015. Nordic best practices relevant for UNEP 10 YFP of sustainable consumption and production. Gaia Consulting, 30/06/2015.

HILMA, 2016. Prior notice. HSY: The testing and evaluation of new methods of treating and utilizing digested sewage sludge and other biomasses. HILMA 11.3.2016.

ISKU, 2016. Life-cycle service for furniture. https://www.isku.fi/työymparistot/elinkaaripalvelut [www, 5.9.2016].

Jurgilevich, A., Birge, T., Kentala-Lehtonen, J., Korhonen-Kurki, K., Pietikäinen, J., Saikku, L. and Schösler, H., 2015. Transition towards Circular Economy in the Food System. Sustainability, MDPI.

Karlstad, M., 2016. Circular procurement, City of Oslo. Presentation in Nordig Green Growth Seminar in Copenhagen, 10.11.2016.

Lojer, 2014. Lojer Rental Beds for Home Hospice Car Patients in Helsinki. Lojer News 7.1.2014. 
MVO Nederland, 2015. Circular Procurement Guide. Available at http://mvonederland.nl/circularprocurement-guide

NewForesight, 2014. Circular Procurement: First working group meeting. Available at: http://www.newforesight.com/news/circular-procurement-first-working-group-meeting/ [www, visited 10.5.2016].

Pape-Mustonen, T., 2015. Särki kannattaa käyttää kalapihviin kaatopaikalle viemisen sijaan. Maaseudun tulevaisuus 12.11.2015.

Philips, 2016. We are embracing circular procurement as a key driver of the circular economy. http://www.philips.com/a-w/about/company/suppliers/supplier-sustainability/ourprograms/circular-procurement.html [www, visited 10.8.2016].

Ryding, S-O., 2012. Environmental-, economic and social considerations in public procurement. The Swedish Environmental Management Council, Report 2012:1.

Stara, 2014. Ida Aalbergin puisto syntyi kierrättämällä.

http://www.hel.fi/www/stara/fi/puistoissa/tyotjatekijat/ida-aalbergin-puisto-syntyikierrattamalla [www, 12.12.2016].

Suikkanen, J. and Nissinen, A., 2017. Circular Economy and the Nordic Swan Ecolabel. How the Nordic Swan Ecolabel steers Products towards Circular Economy: A Review of the Product Specific Criteria and Case Studies. Manuscript 20 July 2016, 53 P., Finnish Environment Institute.

UNEP, 2015. Using product-service systems to enhance sustainable public procurement. Technical report, May 2015.

UPM Profi, 2016. UPM Biocomposites - The composite manufacturer. http://www.upmprofi.com/About/composite-manufacturer/Pages/Default.aspx [www, 10.12.2016].

Van Geet, C., 2014. Circular Economy + Green Public Procurement. Ministry of Infrastructure and the Environment, the Netherlands. Presentation in the EU GPP Advisory Group, 25.3.2014.

Witjes, S. and Lozano, R., 2016. Towards a more Circular Economy: Proposing a framework linking sustainable public procurement and sustainable business models. Resources, Conservation and Recycling, 112:37-44. https://doi.org/10.1016/j.resconrec.2016.04.015 


\section{Sammanfattning}

Syftet med cirkulär upphandling är slutna materialloopar och värdebeständighet, vilket exempelvis uppnås genom återtillverkning och återanvändning av varor och material flera gånger på ett cirkulärt sätt som inte leder till skadliga effekter på miljön. Sammantaget uppfyller cirkulär upphandling målen för hållbar upphandling: värdeskapande, socialt välbefinnande och miljöförbättringar.

Under den här studien utarbetades fyra metoder för cirkulär upphandling: upphandling av varor av bättre kvalitet i cirkulära termer, upphandling av nya cirkulära varor, användning av affärskoncept som stödjer den cirkulära ekonomin och slutligen investeringar i cirkulära ekosystem.

Goda exempel på cirkulär upphandling finns i Danmark, Finland, Sverige och Norge. Under studien identifierades flera fall och potentiella sektorer för cirkulär upphandling med avseende på allmänhetens behov och inköpsvolym. Vid konstruktion och renovering av byggnader kan material och rivningsavfall återvinnas enligt kriterier och villkor som anges i kontraktet. Vid byggande av väginfrastruktur kan betydande besparingar i material och pengar göras om sekundära material från arbetsplatsen eller dess närhet används. Inom energi- och transportsektorerna kan lokala cirkulära system skapas genom att produktionen av bioenergi utvecklas. Vid avloppsvattenrening kan den cirkulära ekonomin främjas genom effektivare återvinning av näringsämnen och utveckling av tillhörande teknik och affärskoncept. Potential finns för varugrupper som apparater, möbler och textilier.

De fall som undersöks i den här studien visar att prestationsbaserad upphandling, användning av livscykelkostnader och kriterier för återanvändning och återvinning av material har gynnat cirkulär upphandling. Dessutom har upphandlande av tjänster $\mathrm{i}$ stället för varor lett till miljövinster.

Marknadsdialog och samarbete mellan olika aktörer i leverantörskedjorna är viktigt för den cirkulära upphandlingens framtida utveckling. Det är nödvändigt att ta hänsyn till hela kedjan av tillverkare, leverantörer, logistik, ombearbetning och slutmarknader såväl som konsumenter. Dessutom är utbildning av upphandlare avgörande för att nya metoder ska anammas. 



\section{Appendix 1}

Overview of different product categories and groups with associated types of criteria as provided by the National Agency for Public Procurement (Sweden) in their database regarding suggestions for procurement criteria.

Table 1: Product categories and criteria with regard to circular procurement in the criteria respository at NAPP

Product category
IT and telecom
Documentary products
AV products
Computers and screens
Building and real estate
New residential buildings
Refurbishment of residential building
New local buildings
Refurbishment of local buildings
Kitchens
White goods
Air filters
Indoor lighting
Outdoor lighting
Electricity
Road and construction works
Forestry

\section{Type of criteria}

Recycling system for used materials.

Environmental and health aspects for toner powder.

Mercury content in lighting equipment.

Information about material choices.

Waste disposal volumes.

Optimisation of material choices.

Object-related environmental plan.

Water-saving taps.

Urban run-off handling.

Energy-efficient windows.

Optimisation of materials, goods, chemical products.

Routines for handling of water overflow/leakages.

Plan for providing information about material choices.

Routines for systematic environmental work.

Energy recovery in effluent indoor air.

Life cycle cost calculations (LCC).

Biocide-free materials.

Life span of lighting materials.

Routines for waste handling by suppliers.

Chemical products.

Control systems for light optimisation.

Mercury content in lighting equipment.

Efficient operations sub-suppliers.

Cleaning and chemicals

Cleaning services

Chemical/technical products

Material properties with regard to bioaccumulation.

Material properties with regard to environmental hazards.

Consideration of significant environmental aspects.

Continuous follow-up activities.

Provision of safety data sheets.

Vehicles and transportation

Passenger transport

Provision of safety data sheets.

Transport of goods

Vehicles

Fuel

Information about reduced environmental impact.

Alternative fuels.

Tracking systems.

Producer responsibility.

Tyres

Offices and textiles

Furniture

Labelling of plastic.

Textiles and leather

Content of dangerous substances.

Paper products

Packaging materials for reuse. 
Food and catering services

Meat, chicken, turkey

Milk, egg, fish, shellfish

Fruit, corn, sugar

Coffee, tea and cocoa

Meal services, catering

Kitchen services

Beverage vending machines

Health services and care

Pharmaceuticals

Water treatment facilities

Medical or technical equipment

Care services

Cleaning and textile service
Traffic planning

Waste handling.

Routines for quality assurance.

Energy saving functions for vending machines.

Raw water intake.

Systems for the handling of chemicals.

Life span and guarantees for products.

Optimisation of energy efficiency.

Automatic low-energy levelling for washing and disinfection equipment.

Water use for washing and disinfection equipment.

Automatic low-energy levelling for ultra-sound equipment

Routines for waste handling

Energy-efficient driving

Water repellent treatments

Dirt- and oil-repellent functions

Pre-schools

Toys, hobby materials

Access to spare equipment

Labelling of plastics

Dirt- and oil-repellent functions

Furniture, textiles, leathe 


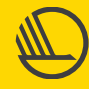

Nordic Council of Ministers

Ved Stranden 18

DK-1061 Copenhagen K

www.norden.org

\section{Circular Public Procurement in the Nordic Countries}

This report provides a framework for circular procurement and discusses its possibilities to promote circular economy. Several best practice examples in Denmark, Finland, Sweden and Norway illustrate how and in which sectors and product groups circular procurement could be applicable. Different approaches to circular procurement and tendering criteria supporting circular aspects are also illustrated.

The study was carried out in Nordic co-operation by Finnish Environment Institute, IVL Swedish Environmental Research Institute and Copenhagen Resource Institute. The project was financed by the Nordic Council of Ministers (NCM), administrated by the NCM Sustainable Consumption and Production Working Group and guided by a steering group consisting representatives from Denmark, Finland, Iceland, Norway and Sweden. 